\title{
UNDERSTANDING CORPORATE PENSION PLANS
}

\author{
by
}

Edmund A. Mennis, C.F.A.

and

Chester D. Clark, F.S.A.

ANALYSTS

RESEARCH

FOUNDATION 
This monograph is dedicated to Roger F. Murray, S. Solan Colt Professor Emeritus of Banking and Finance of the Graduate School of Business, Columbia University. His years of service, total dedication and significant contribution to the financial analysts profession is well recognized and appreciated.

Copyright (C) 1983

by

The Financial Analysts Research Foundation

Charlottesville, Virginia

All rights reserved.

ISBN 978-0-943205-59-5 


\section{CONTENTS}

Preface $\ldots \ldots \ldots \ldots \ldots \ldots \ldots \ldots \ldots \ldots \ldots \ldots \ldots \ldots$

I. Introduction: Understanding Employee

Benefit Plans ................. 1

II. Administrative Aspects of Employee

Benefit Plans ................ 4

III. Investment Policies and Guidelines . . . . . . . 13

IV. Primary Functions of the Actuary......... 25

V. Additional Perspectives on Pension Plans ....... 53

VI. Some Myths About Pension Plans ..........6 63

Appendix .......................... 67

Glossary $\ldots \ldots \ldots \ldots \ldots \ldots \ldots \ldots \ldots \ldots \ldots \ldots \ldots$

Bibliography $\ldots \ldots \ldots \ldots \ldots \ldots \ldots \ldots \ldots \ldots \ldots \ldots$ 


\title{
THE FINANCIAL ANALYSTS RESEARCH FOUNDATION AND ITS PUBLICATIONS
}

1. The Financial Analysts Research Foundation is an autonomous charitable foundation, as defined by Section 501 (c)(3) of the Internal Revenue Code. The Foundation seeks to improve the professional performance of financial analysts by fostering education, by stimulating the development of financial analysis through high quality research, and by facilitating the dissemination of such research to users and to the public. More specifically, the purposes and obligations of the Foundation are to commission basic studies (1) with respect to investment securities analysis, investment management, financial analysis, securities markets and closely related areas that are not presently or adequately covered by the available literature, (2) that are directed toward the practical needs of the financial analyst and the portfolio manager, and ( 3 ) that are of some enduring value. The Financial Analysts Research Foundation is affiliated with The Financial Analysts Federation, The Institute of Chartered Financial Analysts, and the University of Virginia through The McIntire School of Commerce.

2. Several types of studies and publications are authorized:

A. Studies based on existing knowledge or methodology which result in a different arrangement of the subject. Included in this category are papers that seek to broaden the understanding within the profession of financial analysis through reviewing, distilling, or synthesizing previously published theoretical research, empirical findings, and specialized literature;

B. Studies that apply known techniques, methodology, and quantitative methods to problems of financial analysis;

C. Studies that develop new approaches or new solutions to important problems existing in financial analysis;

D. Pioneering and original research that discloses new theories, new relationships, or new knowledge that confirms, rejects, or extends existing theories and concepts in financial analysis. Ordinarily, such research is intended to improve the state of the art. The research findings may be supported by the collection or manipulation of empirical or descriptive data from primary sources, such as original records, field interviews, or surveys.

3. The views expressed in this book and in the other studies published by the Foundation are those of the authors and do not necessarily represent the official position of the Foundation, its Board of Trustees, or its staff. As a matter of policy, the Foundation has no official position with respect to specific practices in financial analysis.

4. The Foundation is indebted to the voluntary financial support of its institutional and individual sponsors by which this and other publications are made possible. As a $501(\mathrm{c})(3)$ foundation, contributions are welcomed from interested donors, including individuals, business organizations, institutions, estates, foundations, and others. Inquiries may be directed to:

\author{
Research Director \\ The Financial Analysts Research Foundation \\ University of Virginia \\ 2015 Ivy Road, Suite 102 \\ Charlottesville, VA 22903 \\ (804) 924-3051
}




\section{THE FINANCIAL ANALYSTS RESEARCH FOUNDATION}

\section{Board of Trustees and Officers}

Walter P. Stern, C.F.A., President Capital Research Company 280 Park Avenue

New York, New York 10017

Alfred C. Morley, C.F.A., Vice President Frank Russell Investment Company P.O. Box 1591

Tacoma, Washington 98401-1591

Edus H. Warren, Jr., C.F.A., Secretary Capital Research Company 280 Park Avenue New York, New York 10017

James R. Vertin, C.F.A., Treasurer Alpine Counselors 136 Pecora Way Menlo Park, California 94025

Richard F. DeMong, C.F.A., Research Director McIntire School of Commerce Monroe Hall - University of Virginia Charlottesville, Virginia 22903

John C. Burton

Dean and Arthur Young Professor of Accounting \& Finance

Columbia University

101 Uris Hall

New York, New York 10027

Charles A. D'Ambrosio, C.F.A.

Professor of Finance

Graduate School of Business

Administration

University of Washington

Seattle, Washington 98195

M. H. Earp, C.F.A.

Brittany Associates, Inc.

P. O. Box 26177

Dallas, Texas 75226

Charles D. Ellis, C.F.A.

Greenwich Research Assoicates

Office Park Eight

Greenwich, Connecticut 06830

President, The Institute of Chartered Financial Analysts

William S. Gray, III, C.F.A.

Harris Trust \& Savings Bank

111 West Monroe Street

Chicago, Illinois 60690

Jay O. Light

Harvard Business School

Baker 331

Boston, Massachusetts 02163

Walter S. McConnell, C.F.A.

Vaughan, Nelson, Scarborough \&McConnell

6300 Texas Commerce Tower

Houston, Texas 77002
Edmund A. Mennis, C.F.A.

Consultant to Investment Management 405 Via Chico, Suite 7

Palos Verdes Estates, California 90274

Robert D. Milne, C.F.A.

Duff \& Phelps Investment Management Co.

710 Ohio Savings Plaza

Cleveland, Ohio 44114

Roger F. Murray

S. Solan Colt Professor Emeritus of Banking and Finance

Graduate School of Business

Columbia University, P.O. Box 669

Wolfeboro, New Hampshire 03894

George W. Noyes, C.F.A.

Standish, Ayer \& Wood, Inc.

1 Beacon Street

Boston, Massachusetts 02116

Matthias Plum, Jr.

172 Beacon Street

Boston, Massachusetts 02116

Chairman, The Financial

Analysts Federation

William G. Shenkir

Dean, McIntire School of Commerce

Mon roe Hall, University of Virginia

Charlottesville, Virginia 22903

A. A. Sommer, Jr.

Morgan, Lewis \& Bockius

1800 M Street, N. W.

Washington, D. C. 20036

Jack L. Treynor

Treynor-Arbit Associates

111 West Jackson Boulevard

Chicago, Illinois 60604

Donald L. Tuttle, C.F.A.

Professor of Finance

Indiana University

Graduate School of Business

Bloomington, Illinois 47405

Jerome L. Valentine, C.F.A.

Consultant

2825 South Logrun Circle

Woodlands, Texas 77380

Arthur Zeikel

Merrill Lynch Asset Management, Inc.

633 Third Avenue

New York, New York 10017

Katherine B. Russo

Executive Secretary 


\section{PREFACE}

Finding a successful solution to the complex problem of investing a pension fund, especially one created by a defined benefit plan, depends upon reaching a clear understanding of the structure of its commitments. This step, which logically precedes the definition of investment objectives, does not come easily to an asset manager untrained in employee benefits and actuarial science. The purpose of this monograph is to facilitate the process of understanding fund characteristics.

At the inception of a defined benefit plan, the assets are so small in relation to the ultimate structure of liabilities that an asset manager can turn directly to setting investment objectives because plan characteristics will affect investment policies only in the distant future. Several decades ago, most public and private pension plans were in those early stages of development. In contrast, today's retirement programs, under the funding requirements of ERISA and after a long period of the maturing process, require a full knowledge of the factors affecting future contributions and benefit payments as they determine future asset growth. As corporate financial officers have properly become more concerned with pension fund management, moreover, they expect asset managers to have a clear understanding of the full range of factors involved.

Assisting asset managers in becoming knowledgeable students of pension plans requires expertise and experience in both investment management and actuarial science. Since strong qualifications in both disciplines are seldom found in a single person, the Research Foundation trustees recruited a team of experts for this assignment.

Ed Mennis has had a lifetime of investment management executive experience (Wellington Management Company, Republic National Bank of Dallas, and Security Pacific National Bank) but is best known to financial analysts for his many writings, as editor of The C.F.A. Digest, and as a recipient of the Nicholas Molodovsky Award. He has become a consultant to investment management since retiring as chief executive of Security Pacific Investment Managers, Inc. 
Ed's partner in this joint venture, Chester Clark, became a Fellow of the Society of Actuaries in 1967 while practicing his profession at the John Hancock Life Insurance Company. Following a stint with New England Mutual Life as Group Actuary, he joined Towers, Perrin, Forster \& Crosby. This manuscript was authored while he was a vice president of this leading actuarial consulting firm, where he was particularly involved in the design and administration of corporate pension plans. He currently is associated with William M. Mercer Incorporated in Boston.

On many occasions, we have observed the inability of actuaries and asset managers to communicate effectively. This publication has successfully solved that problem by the device of coauthorship, which means that the writers have had to reach a common understanding on all major points. Financial analysts are the beneficiaries of this reconciliation of perspectives.

Roger F. Murray 


\section{CHAPTER I}

\section{INTRODUCTION: UNDERSTANDING EMPLOYEE BENEFIT PLANS}

Corporate sponsors are taking a harder look at their employee benefit plans. Clearly the Employee Retirement Income Security Act of 1974 (ERISA) contributes to this increased attention by formally requiring that pension plans be run solely in the interests of plan participants and by making plan fiduciaries personally liable for any breach of fiduciary duties. The growth in plan assets also draws the attention of senior management; when a plan's size exceeds the assets of the largest corporate division or perhaps the total market value of the outstanding corporate stock, the pension plan can no longer be a matter of casual corporate interest. The most important reason for capturing management's attention, however, is the rising costs of these employee benefit plans, which require increased contributions from the employer with a resulting negative impact on corporate profitability.

Rising costs are caused by several factors. Competitive pressures or labor negotiations result in improved benefits as well as the proliferation of additional benefit plans, such as thrift, stock ownership, profit sharing and welfare plans, in addition to the basic pension plan. But additional factors have a greater effect on costs. Investment returns of many funds in the past decade have frequently been below those assumed in many actuarial calculations, and increased corporate contributions have been necessary to make up the difference. An even greater reason for higher costs is inflation. Pension benefits are based more and more on salary levels in excess of those assumed by the actuary and also on salary levels at the end of the employee's career rather than a lifetime average salary.

As pension costs exceed or investment results fall below the estimates the actuary used in recommending the annual contribution, actuarial losses are incurred that must be made up. The actuary does not add the total loss in any year to the succeeding year's contribution but rather amortizes the loss over future years, usually 15 years or less. However, in an inflationary period these losses tend to persist, so that the incremental costs accumu- 
late with the passage of time and they can become a significant part of the total annual contribution.

What, then, are senior managements doing in the face of these rising costs? At a minimum, they are getting more involved in the pension plan process, with more frequent reports on the plan's status made to the board of directors or some senior management committee. In addition, greater attention is paid to the actuary's annual report and the assumptions made therein as well as to the selection and the investment results of the investment manager(s). This situation is significantly different from that of a decade ago, when plan assets were smaller and senior management involvement much less. The question now is not whether senior management is involved but how.

One of the more obvious steps in increased involvement is a larger claim on senior management time, including formal meetings devoted to the various aspects of employee benefit plans. Another development is upgrading the status of the officer or staff group involved with employee benefit plans. More fundamental, however, is a review and reorganization by the company of all the aspects of the employee benefit process. This subject is treated in greater detail in the next section. At this point it is sufficient to indicate that the key parts of the process are administration, investment, and funding.

The purpose of this monograph is to review how the various parts of the employee benefit plan process function now and how they may be evolving. Few, if any, companies will be structured exactly as we describe, and not all the functions will be performed as outlined. Given the different sizes of companies and plans as well as different management styles, diversity is to be expected; however, certain fundamental principles should be common to most companies. This monograph may be useful as a checklist or challenge to some or as a source of information to others.

The sections that follow discuss in turn the administrative functions of the corporate sponsor, the investment aspects of the fund, the role of the actuary, and certain issues of current significance in the employee benefit area. Then, in light of the discussion, a section is devoted to analyzing certain widely held beliefs about pension plans. The paper contains a glossary of actuarial terms that may help the reader to sort out and understand 
better some of the complexities of the actuary's work and also a checklist of factors the corporate plan sponsor might consider in managing employee benefit plans. Finally, a bibliography is included of material that was helpful in preparing this monograph or references the authors have found useful. 


\section{CHAPTER II}

\section{ADMINISTRATIVE ASPECTS OF EMPLOYEE BENEFIT PLANS}

The corporate sponsor is at the center of any employee benefit structure. The corporation must balance the interests of employees and shareholders, decide who gets what benefits when, make contributions and pay benefits, and assume responsibility for the prudent investment of the plan's assets and for the plan's administration.

\section{Administrative Structure}

The typical employee benefit management structure for a relatively large company would be similar to that illustrated in Figure 1. All these functions are necessary but many may be performed by the same person on the corporate staff if the size of the corporation or the plan does not warrant so elaborate a structure.

Since the passage of ERISA, the ultimate responsibility for the plan rests with the named fiduciaries, who are responsible for carrying out the provisions of the governing instrument of the plan solely in the interests of plan participants and for the exclusive purpose of providing benefits to them and defraying reasonable administrative expenses. The practice of corporations in naming fiduciaries varies. Some corporations name senior corporate officers (either a single officer or a committee); others name the board of directors or their committees, while others name the corporation itself. (Investment managers also are named fiduciaries but for investments only.)

To assist in carrying out their responsibilities, the controlling group of the pension plan can draw upon a variety of resources, both internal and external to the corporate staff. The human resources staff or the personnel department can recommend benefits to be granted based on the needs and desires of the labor force. Other influences on benefits can be competitive practices in the industry and union pressures. The legal staff can review collective bargaining agreements and investment management agreements for compliance with the law. They also can advise on actions that might be considered a breach of fiduciary duty by any of those involved in plan management and administration, 
FIGURE 1

TYPICAL EMPLOYEE BENEFIT MANAGEMENT STRUCTURE

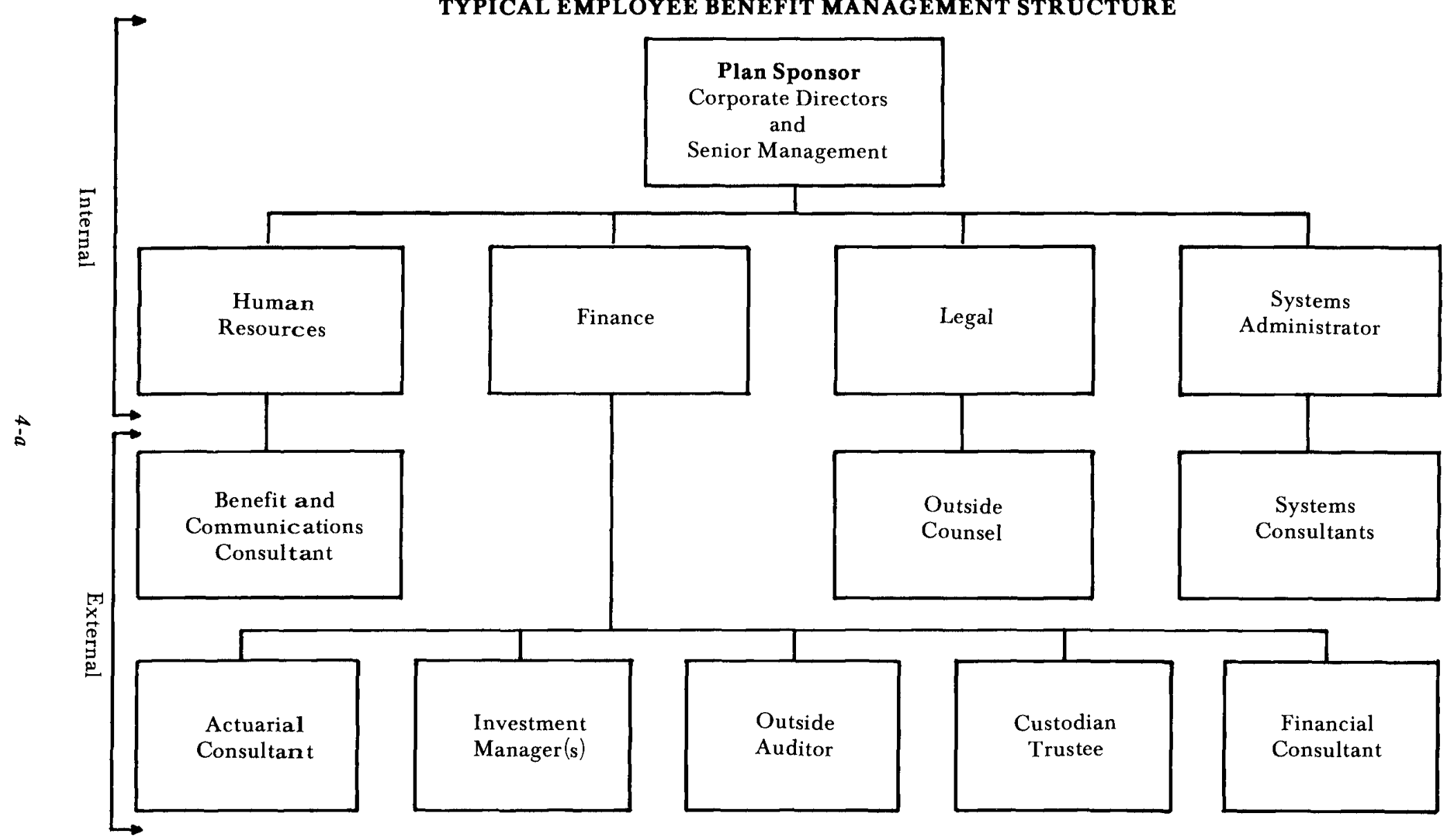


or assist in the interpretation of the many government regulations covering pension plans. Systems administrators can evaluate the benefit payment mechanisms and administer the payment of benefits; this function can be performed either within or outside the company.

Important as these services may be, the focus in this monograph is primarily on areas grouped under the finance function. The corporate staff with primary duty for administration of the pension plan often reports to the senior corporate finance officer. The custodian of the plan's assets (who often also acts as trustee) normally reports to the corporate plan administrator. Financial or pension plan consultants and the independent auditor are part of this group. Finally, the other two participants in the pension plan process-the actuary and the investment manager - are responsible to the senior financial officer or a staff member who reports to him. The investment and actuarial aspects of these plans are discussed later.

Regardless of whether the functions described as belonging to the corporate sponsor are performed or not or are performed by a few people rather than a large staff, the responsibilities fall generally into two categories: (1) evaluation of the characteristics of the plan and the company's ability to afford it; and (2) setting general policies and guidelines for the administration of the plan and the investment of its assets. An additional responsibility many corporations are assuming is management of some or all of the plan assets.

\section{Evaluating the Characteristics of the Plan and the Company}

Determining the characteristics of a corporate pension plan falls roughly in to two parts:

1. What total compensation package can the company afford?

2. Given this constraint, what employees will be covered and what benefits will they receive? 
The answer to the question of what the company can afford requires a balancing of the long-term interests of the shareholders and the employees. In some companies, the owners also are the key employees, so that any conflict is more apparent than real. In a large corporation where ownership is diffused, often indirect, and ordinarily not related to employment, pension benefits are viewed as necessary to obtain and retain an interested, skilled, and hardworking labor force. The longer-term advantages of such a labor force must be balanced against the costs to the company.

Other factors that must be considered are the size and cyclical volatility of the company's income. In addition, the ability of the company to control its pricing and its costs must be taken into account. Pension benefits are a so-called "fringe" benefit, but these types of benefits have become a significant part of total compensation costs. Such costs, which are only indirectly related to the volume of the company's business, should not be an undue burden in a bad year.

A pension plan, once established, is almost an irreversible benefit; in any event, terminating the plan requires arrangements with the federal government. The assets of the plan may not be sufficient to cover the basic benefits when the plan is terminated, or the government may terminate the plan because the company is unable to pay benefits when due or because the plan does not meet minimum funding standards. In these cases, the Pension Benefit Guaranty Corporation (PBGC) becomes involved; plan termination is discussed in a later section of this chapter.

It is clear that defining the characteristics of a corporate pension plan must be done carefully. Pension costs can become a significant burden to a corporation and have a meaningful impact on its profitability, particularly if the company is subject to cyclical variations in earnings or if it has an older work force or a low ratio of active to retired employees. From a shareholder's point of view, large unfunded pension liabilities can have an important influence on the credit worthiness of the company and on the valuation of the company's stock. 


\section{Determining Type of Plan}

Having decided that a corporation can afford and should offer some type of employee benefit plan, the next step is to determine what type of plan or plans the company should adopt.

Employee benefit plans that provide some form of deferred benefits (that is, benefits deferred until after the employee retires) fall into two broad categories. A defined contribution plan provides an individual account for each participant and benefits are based upon the amount contributed by the company, or by the company and the employee, to that account, together with the investment results of the account. A defined benefit plan specifies a definite formula under which benefits are determined, and employer contributions are determined actuarially to assure the availability of sufficient funds to provide the benefits promised in the plan.

A recent study by the Department of Labor indicated that about $30 \%$ of the nearly one-half million plans in the United States were defined benefit plans, but that they covered almost $70 \%$ of the participants in all plans. Defined benefit plans had two and one-half times the assets of defined contribution plans, and twothirds of the defined benefit plans had more than 100 participants. The typical defined contribution plan is much smaller; three-quarters of these plans had fewer than 100 participants.

Among defined contribution plans are the following:

1. Profit-sharing plans, which provide for contributions to a plan established and maintained by an employer for participation in profits by employees and their beneficiaries. To be tax-exempt, the plan must have a definite, predetermined formula for contributions and distributions.

2. Stock bonus plans, where contributions are not dependent upon profits and benefits are distributed in company stock.

3. Employee stock ownership plans (ESOP), where an individual account is established to permit an employee to invest in securities of the employer. Ordinarily, the 
employer contributes to defray some plan costs or matches a portion of the employee's contribution.

4. Money purchase plans, where the employer usually contributes a level amount or a specified percent of the employee's compensation, with the benefits ultimately received dependent upon what the total contributions plus investment earnings will purchase at retirement.

5. Savings or thrift plans, where the employee contributes a limited percent of his salary and his contribution is partially matched by the employer. The funds are usually invested in various stock, bond, or cash equivalent funds, often selected by the employer but with the allocation determined from time to time by the employee.

6. Under recent tax law revisions, several new versions of Individual Retirement Accounts (IRA) have been permitted in which the company may pay the costs. Under one version, the company makes payroll deductions of after-tax employee dollars for contributions to a regular IRA established by the employee. Under another version, the employee may make pretax contributions to a savings or thrift plan sponsored by the employer.

7. Another type of arrangement is now permitted under Section $401(\mathrm{k})$ of the Internal Revenue Code. The employee may make pretax contributions above the $\$ 2,000$ limit of IRAs, the employer can match the contribution, and the employee has access to the funds in the event of hardship, termination, or retirement. This plan is subject to complex discrimination tests to prevent higher-paid employees from benefiting disproportionately.

Defined benefit plans fall into two categories: insured and noninsured. Insured benefits, as the name implies, are purchased from an insurance company, with the employer purchasing an annuity that will assure the agreed-upon benefits at retirement. Noninsured plans, which account for a larger percentage of pension assets, ordinarily are invested in a portfolio of securities or other financial assets, with the annual contributions actuarially 
determined so that funds will be available to meet the annual benefits in the foreseeable future. (A later chapter will discuss in more detail the role of the actuary in estimating the amount of the contributions.)

\section{Employee Coverage}

Having determined the type or types of plans to be offered by the company, additional decisions regarding its features still must be made. The employees to be covered must be determined. Generally, employee eligibility is at the discretion of the employer, except that (under ERISA) employees must be eligible to participate one year after their first employment date (assuming they have reached the age of 25) and the plan must not discriminate in favor of executives, highly paid employees, or shareholders. The law also has minimum coverage requirements, except that an employee hired within five years of the retirement age specified in a defined benefit plan may be excluded. Employee contributions are usually not required in private pension funds in the United States; only about $8 \%$ of total contributions are made by employees in this country.

\section{Vesting}

Another decision a company must make regarding its plan concerns vesting, i.e., the conditions under which an employee has a right to receive a pension benefit even if he leaves his job. Vesting also is covered under ERISA.

Benefits derived from employee contributions receive full and immediate vesting. ERISA minimum requirements for vesting with respect to employer contributions are established under three alternatives:

1. An employee is not vested at all until after 10 years of service but is $100 \%$ vested thereafter. This method is used by about $80 \%$ of all companies in the United States and is preferred by large companies and companies with large plan assets.

2. An employee is at least $25 \%$ vested after five years of service, and then is vested an additional $5 \%$ for each of the next five years, and then $10 \%$ for each of the next 
five years. This method is used by about $10 \%$ of all companies-most often by companies with smaller plan assets.

3. The third method used is the "Rule of 45 ", where an employee with five years of service is $50 \%$ vested if his age plus years of service equal 45 . For each year of service thereafter, the percentage vested increases $10 \%$ per year up to $100 \%$. An employee with 10 years of service must be at least $50 \%$ vested regardless of age, with the percentage increasing by $10 \%$ for each additional year of service so that he will be $100 \%$ vested after 15 years of service.

\section{Benefit Payments}

Benefit payments may be in the form of a lump sum, an annuity payable over the life of the participant or the participant and his beneficiary, or in installments for a specific time.

In a defined benefit plan, the benefit ordinarily is defined in terms of earnings, either as a flat percent of earnings or as a percent of earnings times the number of years of service. For example, the annual benefit could be equal to $1 \%$ of the average earnings for the final three years of employment multiplied by the number of years of service. Sometimes the benefit is a stated dollar amount per year of service. In a defined benefit plan, benefits were initially set by law at no greater than $\$ 75,000$ a year or $100 \%$ of the average of the participant's highest three consecutive years of compensation, whichever is less, subject to costof-living increases. The limit is now set by law at $\$ 90,000$ until 1986, when the dollar limits will be adjusted for post-1984 costof-living increases (as measured by the index used to adjust those increases).

In a defined contribution plan, the retirement benefit is the annuity that can be purchased at retirement based upon amounts allocated to the participant's account. For example, the benefit is the annuity that could be purchased based upon an annual contribution of $1 \%$ of an individual's salary, plus investment earnings. Under the defined contribution plan, contributions for the account of any one person were set initially by law at no more than $\$ 25,000$ a year or $25 \%$ of the participant's compensation, 
whichever is less, again adjusted for cost-of-living increases. The limit is now set by law at $\$ 30,000$, but it will be adjusted in 1986 by the same formula as for the defined benefit plan.

\section{Other Corporate Decisions}

Still other decisions must be made about pension plans. The retirement age must be decided, and consideration must be given to provisions for early retirement and the resulting adjustment of benefits. Employees by law may work beyond age 65 until they have 10 years of participation in the plan.

When a retirement plan provides that a participant may take his benefits in the form of an annuity, as most do, the law requires that the plan provide a joint and survivor annuity if the participant has been married for one year before retirement and does not give up the survivor annuity in writing. The survivor annuity must not be less than one-half of the annuity payable to the participant while he and his spouse were both living.

In the United States, private pension plans are viewed as supplements to the Social Security system. Almost all workers are covered by Social Security, which is supported (thus far, at least) by contributions paid equally by employers and employees. Some pension plans provide for integration of benefits with those received from Social Security. However, vested benefits in a plan may not be reduced as a result of increases in Social Security benefits after the date a participant terminates or retires.

When an employee changes jobs, normally his pension interest and benefits are not transferred to the new employer nor does he immediately receive benefits from the plan. However, the participant's vested interest must be retained by his previous employer and paid at the specified retirement date. Consequently, some retirees may receive benefits from more than one plan.

Many plans also provide some form of death benefit to the employee's beneficiary, should death occur before retirement.

\section{Plan Termination}

A company may terminate an employee benefit plan. However, a plan qualified for favorable tax treatment under the Internal 
Revenue Code must provide that, in effect, each affected participant becomes fully vested in his accrued benefit at the time of termination. ERISA also provides that, for defined benefit plans, the Pension Benefit Guaranty Corporation (PBGC) must be notified.

The PBGC was established as part of ERISA and is a selffinancing agency within the Department of Labor. If plan assets are adequate to pay benefits, PBGC permits the plan to be terminated; thus far, $97 \%$ of terminated plans have been in this category. If plan assets are insufficient, PBGC will, within certain restrictions, pay vested benefits to terminated plan participants. PBGC will take over the assets of the plan and also may hold the sponsoring company liable for $100 \%$ of the unfunded actuarial present value of the benefits to be paid by PBGC up to $30 \%$ of the corporation's net worth. (PBGC also may, under certain circumstances, go to court to force the termination of a plan, but this right has not been exercised yet.)

As additional sources of funds to pay benefits, PBGC has the ability to borrow up to $\$ 100$ million from the U.S. Treasury as well as annual insurance premiums paid by all qualified, active plans on a per-participant basis. The premium originally was set at $\$ 1$ perparticipant, later raised to $\$ 2.60$, and a request to increase it to $\$ 6$ is now pending before Congress. Nevertheless, the failure of a major corporation with large unfunded pension liabilities would put a severe strain on the resources of PBGC, and Congress would have to determine whether the premium must be increased further or the guaranteed portion of the benefits reduced. Congress is currently considering some modifications of ERISA that would correct the inequity of sound, well-funded plans bearing the cost of the failure of unsound plans. For example, the premium rate might be related in some way to the PBGC's exposure, if such a risk-related charge can be devised.

The maximum benefit insured by PBGC is the equivalent of a single life annuity payable beginning at age 65 equal to $100 \%$ of the participant's average wage during his five highest-paid consecutive calendar years of participation, subject to a monthly limit and adjustments for inflation. This limit originally was $\$ 750$ a month; by 1983 it had increased to $\$ 1,517.05$. 


\section{CHAPTER III}

\section{INVESTMENT POLICIES AND GUIDELINES}

Most of the corporate decisions described in the previous section are made at the time the plan is established and ordinarily are subject to periodic review thereafter. Decisions regarding the investment of the plan's assets are ongoing and subject to more frequent and critical review. The primary reason for this interest is the significant impact investment results can have on the contributions required; a rough rule of thumb is that a $1 \%$ change in the return on assets can have a $25 \%$ impact on the annual contribution.

In spite of the importance of establishing basic investment policies for corporate pension funds, it is surprising and disturbing that many companies do not get significantly involved in this process. A study of the practices of large corporate pension funds made by Greenwich Research Associates in 1981 revealed that: (1) less than half the companies specified the basic asset mix of stocks and bonds; (2) $60 \%$ gave their portfolio managers full discretion in the amount of cash and cash equivalents to hold; (3) $56 \%$ gave managers full discretion over portfolio diversification; and (4) $63 \%$ left entirely to their managers the volatility permitted in their portfolios. Consequently, the paragraphs that follow suggest practices atypical of those of many companies.

\section{Investment Return Objectives}

With respect to investments, the first task of the corporate sponsor is to set return objectives and broad definitions of characteristics for the investment portfolio that receives the corporate contribution. Setting investment objectives by the corporation for the investment manager or managers was not always considered an important function of the corporate sponsor; objective setting frequently was left to the discretion of the investment manager. However, as funds have grown in size, setting investment objectives has assumed increased importance; written objectives are prepared and then reviewed at regular intervals. Unfortunately, objectives often are stated in very vague terms, such as obtaining the maximum return consistent with prudence. Nevertheless, this problem is getting increased attention, and more specific directions may be expected in the future. 
Initially, we shall discuss investment objectives for defined benefit plans and later consider objectives for defined contribution plans.

In setting investment objectives, the relevant time horizon over which results are to be measured is the most significant decision. Pension funds ordinarily have a long time horizon, especially when contributions will exceed payments for some years. Consequently, it might be expected that the measurement period for the manager also would be long, say, at least three to five years. Although written objectives often are stated that way, the custom of semiannual or annual meetings with managers usually results in reviews concentrating on a much shorter time span.

The two time frames are reconcilable, however. A long-term target rate of return can be set, and then results measured at shorter intervals to see whether the objectives are likely to be reached. For example, if a rate significantly above a target rate is earned in the first two years of a five-year period, the amount needed to achieve the five-year goal is lower for the last three years.

By contrast, if the target rate is missed by a significant amount during the first two years, much greater returns will be necessary for the remainder of the period. The manager may be tempted to increase the risk exposure substantially to meet the target rate, or the corporation must face the possibility that this rate is not attainable. This blending of the two time horizons can provide a much more fruitful dialog between the manager and the corporate sponsor than the more typical review that focuses on "What have you done for me lately?" The question might rather be: "Are we on the path that will enable us to reach our targets or are adjustments necessary?"

Another significant decision in objective setting is whether results are to be measured absolutely or relatively, i.e., with a specific absolute number or a result relative to some market index or some universe of investment managers. The answer to this problem is not simple but may vary depending upon whether the company has single or multiple managers and also whether a measurement objective is being established for the total fund or some of its segments. 
Let us examine first the situation of a fund that has only one manager. Return objectives for the total fund can be set in absolute terms, say, a minimum return over a five-year period that will meet the actuarial rate, or the inflation rate, or some other absolute amount that can be related to the funding-status of the plan. Relative objectives, which are used more frequently, often state that the total fund is expected to do better than the risk-free rate (usually defined as the rate on short-term U.S. Treasury bills), or some stock or bond price index (or a weighted combination of the two), or some universe of investment managers.

All these types of objectives for the total fund are found in corporate pension plans. An absolute minimum return objective for the total fund related to the funding status of the plan would seem to be a logical way for the corporate sponsor to be sure the costs of the plan are under control. On a relative basis, an objective using a risk-free rate may be useful, because it indicates some incremental return should be obtained if investments are made in other than riskless investments. Alternatively, a weighted combination of market indexes could be used to set up a hypothetical portfolio with a predetermined fixed-equity ratio as a benchmark. A reasonable objective then could be to do better than that portfolio, which could be accomplished either by varying the asset mix or by outperforming the appropriate market indexes in the various portfolio segments. The least useful measure would appear to be a universe of other managers, because such a universe is usually composed of a wide variety of managers with different portfolio objectives, different portfolio sizes, and different risk preferences.

For segments of the total portfolio, the usual practice is to set objectives to do better than a particular market index, such as the Standard and Poor's 500 stock index, or the Salomon Brothers or the Lehman-Kuhn Loeb bond indexes. In this context, relative objectives are realistic because the corporation is paying a management fee for better-than-market performance. If this is not obtained over a period of time, the fund would be better off invested passively in some form of an index fund for equities or in a staggered maturity bond portfolio.

The situation for a fund that has more than one manager is somewhat different. Only the corporate sponsor has the overall perspective of the total fund. Consequently, the company must 
assume responsibility for total fund performance and should measure this internally. In this case, using some absolute objective or some relative objective such as the riskless rate or some hypothetical portfolio of weighted market indexes would seem reasonable. Again, if objectives include being somewhere in a universe of other funds, care should be taken that the other funds are comparable in objectives, size, and risk tolerance.

In a multimanager situation, the individual managers can be given objectives to do better than some market index, because the corporate sponsor is paying a fee to receive betterthan-market results. As investment managers become more specialized, movement has been observed to expect managers not necessarily to do better than the market as a whole but to do better than their peer group, i.e., other managers with the same management style. However, if a particular style or type of investment is out of fashion for a period of time, a manager may have superior results in his peer group but his absolute results may have a negative impact on the overall portfolio. If this measurement procedure is used, the corporate sponsor should realize the selection of a manager with a particular style is a corporate decision, and the corporation should measure whether $i t s$ decision accomplished the investment objectives for the plan.

\section{Investment Risk}

The treatment of investment risk probably is the least satisfactory area in the establishment of investment objectives. In spite of all the work published on risk in the investment literature of the past several years, risk tolerance often is not specified in setting investment objectives. Sometimes, statements of risk are made in general terms (e.g., the fund should not suffer a loss in any designated period) or a maximum tolerable decline in asset value is specified. Such specifications of risk are very difficult for an investment manager to deal with. In order to avoid loss, particularly if a short time such as one year is specified, a very significant portion of the portfolio might have to be placed in short-term fixed-income securities with limited volatility of principal, thus restricting the potential rewards a somewhat more aggressive investment posture would provide. Such a strategy would involve, in effect, paying a liquidity premium, in the form of return foregone, not relevant to a pool of assets with little or no liquidity needs. 
Another method of specifying risk is in terms of the acceptable volatility of the portfolio, usually stated in terms of beta, which is a measure of that volatility. For example, the portfolio manager might be constrained to manage a stock portfolio with a beta of not more than 1.10 , which means that, over time, the weighted average volatility of portfolio securities should not be expected to have price fluctuations more than $10 \%$ greater than fluctuations of the market.

The difficulties with such a requirement are twofold. The method of measuring beta must be specified, because different methods of measuring beta will result in different betas assigned to particular stocks and therefore different estimates of the beta of the portfolio. The second problem is that past betas for individual stocks do not necessarily reflect future betas for these same stocks. Although the problem is not large at the portfolio level, a portfolio manager wishing to reduce or increase the beta of his portfolio will have to go at the job with somewhat less than precise tools.

Perhaps the most useful way to define risk is to combine it with some absolute measure of return. For example, if the objective of the portfolio is to achieve an absolute minimum $9 \%$ return, risk can be stated in whatever terms the corporate sponsor wishes of the probabilities of achieving that return. For example, the probabilities of achieving a minimum return of $9 \%$ may be set at $85 \%$; this will result in a certain portfolio structure under certain assumed returns for various types of securities. An additional piece of information this type of instruction provides is that, if a portfolio has an $85 \%$ chance of a $9 \%$ return, it also has a $50-50$ chance of achieving a higher rate of return, which can be calculated.

Another way of defining risk could be to establish return and risk as the selected probability of achieving certain corporate objectives. For example, a return could be specified that would provide a $90 \%$ probability of stabilizing contributions at a certain percent of payroll.

In any event, establishing an absolute minimum return objective provides a clearer guideline for the portfolio manager, especially for the structure of a total fund. Relative measures are better applied to segments of a portfolio, where the results of investing in 
individual asset types can be measured against appropriate market indexes, and the results of several investment managers can be compared.

\section{Returns and Risks for Defined Contribution Plans}

It is difficult to be very specific in discussing return and risk objectives for defined contribution plans because of the considerable variety of such plans and the diverse needs they must satisfy. However, a few generalizations can be made.

Generally, the beneficiaries of such plans are relatively unsophisticated investors. Yet they bear the investment risk inherent in the plan. The benefits they will receive are set by the value of their investment in the plan at the date of their retirement, and this valuation may come at an unfortunate time in the market cycle. Consequently, the beneficiaries are likely to measure investment results over short periods and against whatever alternative investment has been most successful recently.

As a result, investment objectives for such plans generally should be set more conservatively than for plans where the benefit is fixed, regardless of the retirement date. Minimum objectives of keeping pace with the inflation rate or exceeding the passbook savings rate are not unusual. Risk tolerance is not great, so portfolio fluctuations should be low.

\section{Asset Allocation}

Once the investment objectives are set, the next decision involves distribution of the plan's assets. This process is twofold: selecting the types of assets to be used and then determining the amount to be invested in each type.

In the United States, the preponderance of pension plans is invested in familiar financial assets such as bonds, stocks, and cash equivalents. However, investment is growing in other types of financial instruments, such as guaranteed investment contracts, private placements, venture capital investments and options. Portfolios also are being diversified outside of the United States through investment in foreign securities. In addition, investment in real estate (both debt and equity) and oil and gas has been used increasingly. The decision on the types of investments to be 
selected is a function of the expected returns, the risk tolerance of the sponsor, the need of liquidity, and the management skills available.

Once the asset types are determined, the allocation of funds to each asset type must be decided. Although this decision may be arbitrary in many cases, the use of asset allocation models has been increasing. In order to operate most of those models, the expected return for each asset type, the expected variance of this return over time, and the covariance of the return of each asset type with each other asset type must be estimated. Given this information, which should be available from the investment manager, and also given the time horizon and the desired return as set forth in the investment objectives, an asset allocation model can indicate the optimal proportion of the portfolio to be allocated to each asset type selected. (In Chapter V, we discuss some recent academic articles that present a different approach to the issue of investments considered appropriate for a defined benefit pension plan.)

As indicated in the discussion of objective setting, when the fund is managed by a single manager the asset allocation can be left to the manager, although guidance from the corporate sponsor through the objective-setting procedure seems desirable. In a multimanager context, however, only the sponsor has the overview of the total fund, and the asset allocation responsibility should be assumed by the sponsor. If this is not done, the most critical decisions are just not being made, and the sponsor must assume responsibility for the results.

\section{Liability Partitioning}

The conventional approach to pension asset management assumes that one pool of invested pension assets should be regarded as a single portfolio (although possibly with multiple investment managers) having a single level of risk tolerance and acting as an offset to a single pool of pension liabilities. However, the estimated magnitude of the pension liabilities is something less than precise and establishing investment objectives to meet such an uncertain target is not easy. Some corporations have met this problem by making distinctions among the liabilities and offsetting each pool of liabilities with a separate portfolio with appropriate risk and return objectives. 
The initial step taken is to partition the pension fund liabilities. The first group of liabilities is the contractual liability to retired employees, which can be estimated with a considerable degree of accuracy. Unless the corporation voluntarily changes the benefits, only a difference from assumed mortality rates would cause a variance in the actuary's estimate of the benefits to be paid each year for the next 30 years or so. These benefits can be met with a high degree of certainty with the income from a highquality bond portfolio constructed so that interest payments and the maturity of a portion of the portfolio each year match the benefit payments. Many corporations have set up separate bond portfolios dedicated to this purpose.

A second pool of contractual liabilities is for workers who have become vested or legally entitled to pension benefits. Although these liabilities are less well-defined because benefit payments will depend upon salary levels just before retirement, their amount can be estimated with a reasonable degree of accuracy by the actuary, especially if the estimate is confined to those due in the next 10 years. This process concentrates on liabilities to employees 55 and older. Assuming that salaries probably will grow with the inflation rate, a minimum return objective can be set equal to the inflation rate with a high probability of achievement. The size of this portfolio can be set at the present value of the future benefits to be paid to those employees who retire in the next 10 years, and each year a contribution can be made from this portfolio to the retired benefit portfolio.

The third pension liability is all those not considered in the first two categories. These liabilities are mostly contingent or are vested liabilities to be paid in more than 10 years. This portfolio can have a minimum return objective of matching the inflation rate, although the probability of achievement can be less than that of the vested portfolio and the portfolio risk thereby would be increased to enhance the probability of a higher investment return. This portfolio would receive the company's annual contribution, and its assets would be used to make adjustments as necessary each year in the other two portfolios.

The advantages of this process are a better allocation of funds and a clearer delineation of objectives and expected returns and risks. In addition, liability partitioning may make corporate management more comfortable with the assumption of greater 
risk in the total portfolio because of the high degree of assurance provided that certain segments of the plan's total liabilities will be met, regardless of market uncertainties.

\section{Manager Selection}

Although practices may differ with respect to the involvement of the corporate sponsor in objective setting and asset allocation, selection of investment managers is rarely delegated. In terms of dollars of assets, most funds are managed by investment managers outside of the corporation, inasmuch as few companies have the internal expert staff needed to perform this function. Moreover, corporate management may prefer to delegate the fiduciary responsibility for investment, and some companies believe that having outside managers reduces some of the problems with respect to pensions in labor negotiations.

Nevertheless, the decision to manage a portion or all of the pension fund within the organization usually is based upon cost considerations. The point where it may be worthwhile to consider inside management occurs when the fees paid to outside managers are sufficient to support an internal staff to manage those assets. Management fees vary considerably, but they usually start at $0.5 \%$ of assets up to a certain level, say, $\$ 10$ million, and are reduced thereafter. Consequently, when assets exceed about $\$ 300$ million, the company can consider the desirability of internal management as a practical alternative.

The type of assets managed within the organization varies. Cash equivalents often are the first, because cash management is a function ordinarily performed by the staff in the corporate treasurer's department. Fixed-income management or some form of passive fixed-income or equity investment appears to be the next level of involvement. Active equity management generally is the last responsibility assumed.

If outside managers are used, the corporation must establish criteria for their selection and retention. This function often is performed with the assistance of consulting firms that specialize in this activity.

If the fund is of any size, say more than $\$ 50$ million, the corporation also must decide whether one manager or multiple managers 
will be hired. The decision is one of weighing the anticipated improved investment results against the increased fee paid for management. Because most managers have a fee that decreases as assets under management increase, adding managers does increase costs.

In years past, it was customary to hire "balanced" managers, i.e., managers who ran portfolios balanced among stocks, bonds, and cash equivalents. During this time, most assets were managed by bank trust departments and insurance companies. However, for the past decade or so the trend has been away from balanced managers and also away from bank trust departments. During this period, many new investment management organizations have sprung up, most of whom specialize in some selected area of asset management. Consequently, the blending of managers with different styles and strengths can be a complex problem that few companies care to tackle alone.

Classifying managers by investment styles, either judgmentally or by statistical techniques, has been done as a matter of convenience primarily by consulting firms; most managers prefer to think of themselves as unique. Classifications may be by type of asset managed (bonds, stocks, real estate, oil and gas investments, etc.) or by subsets of types of securities (low p/e stocks, emerging growth stocks, "undervalued" stocks, income stocks, etc.) or by portfolio strategy (market timers, economic sector rotators, etc.).

The many management styles available are not the only reason for the difficulties in selecting managers. Once hired, a manager is very expensive to dismiss. The costs involved here are those associated with the significant revamping of a portfolio, not the least of which are transaction costs. Consequently, a manager search is quite lengthy, with emphasis on organizational structure, personnel and their compensation, decision process, style and philosophy, and, most important, past investment results. Good past results are hoped to be indicative of future results, although the evidence to support this conclusion is not very strong.

Once the manager or managers are selected, the sponsor must determine the amount of discretion to be given to him and also the investment objectives compatible with his style that fit into the total fund objectives. 


\section{Performance Evaluation}

The final task in the area of investments is to establish a monitoring system to evaluate performance and to determine whether the fund's investment objectives have been met. This topic is the subject of a separate monograph published by the Financial Analysts Research Foundation, and it will not be covered at any length here. However, a few comments are pertinent.

The first consideration is how the returns should be measured. Current practice generally advocates two methods. The internal or dollar-weighted rate of return is used to compare results relative to actuarial assumptions or other investment objectives. The purpose of this measure is to see how well the total fund has performed and does not consider the sources of the return. The results can be strongly influenced by the flow of cash into and out of the portfolio, especially in a period of fluctuating market returns. The second method, the time-weighted rate of return, is used to measure the results of the investment manager, and is adjusted to eliminate the effects of the timing of cash receipts or the withdrawal of funds.

The measurement of results usually is made compared with the objectives. In the section on that subject we discussed such items as the time period, the use of absolute vs. relative measures and the identification of risk. Many consulting firms are prepared to provide performance evaluation services, including diagnostic evaluation of the manager's style, a measure of risk-adjusted return, a determination of the sources of return and a comparison of actual results vs. the stated philosophy of the manager.

In spite of the elaborate work done to measure performance, most of it still is on a relative basis. As we indicated earlier, relative results are useful to determine whether a manager has added value for the fee received, but absolute returns also are useful to examine the entire fund and determine whether the objectives have been met in terms of stabilizing contributions or reducing actuarial losses or otherwise meeting stated corporate objectives. In a multimanager situation, a good portion of the investment results of the plan can be attributed to decisions made by the corporate sponsor rather than the investment manager, and these also should be evaluated. Finally, returns are most often examined without consideration of the risks assumed to obtain them. To 
remedy this defect, measures of the volatility of the total portfolio vs. the market, as well as an evaluation of the quality of the individual securities, should be made. 


\section{CHAPTER IV}

\section{PRIMARY FUNCTIONS OF THE ACTUARY}

One of the first things a senior actuarial consultant drums into the head of a promising young protégé is:

The actuary does not determine the cost of a plan. The True Pension Cost is determined by the benefits promised to participants by the plan sponsor and by the investment return.

No statement is of more fundamental importance in understanding the actuary's role in pension funding. The actuary is the architect of a budgeting scheme that assigns the True Pension Cost to specific time periods, usually periods prior to the realization of that true cost. This budgeting process is composed of two general parts: a set of actuarial assumptions and an actuarial method. The set of actuarial assumptions constitutes the actuary's opinion relative to the future course of a whole series of items that will affect the cost of the plan, e.g., interest rates, inflation, mortality rates, employee turnover, etc. The actuarial method is the way in which future costs (as estimated based on the actuarial assumptions) are to be allocated over time so that they can be prefunded in an orderly fashion, e.g., a constant percentage of covered payroll.

There are two major outputs from this budgeting process: (1) an annual contribution level to be charged against the plan; and (2) a set of liabilities that provide some benchmarks against which to measure funding progress. These results are contained in an actuarial report often called an actuarial valuation. The actuarial report usually is produced annually and can be done in varying degrees of sophistication, ranging from a simple recitation of legally required numbers to an elaborate forecast of the future involving a complex statistical model. Special studies relating to valuation matters and consulting involving the design and communication of benefit plans are other services the actuary provides.

The management of fund assets is practically the only aspect of pension work that does not directly involve actuarial firms. 
Unfortunately, too often the plan sponsor makes the separation between his actuary and his investment adviser so complete that little, if any, communication goes on between these two experts so critical to the proper functioning of a pension plan. It is almost as if a corporate CEO never permitted his financial VP, his production VP and his marketing VP to be in the same room together. Even though their functions are different, and they should not be directing each other, it is common sense that these people should meet periodically to discuss general issues, many of which impinge on each of them in slightly different ways.

In the next section, we shall discuss in some detail the critical outputs of an actuarial valuation and the actuarial methods and assumptions upon which these outputs are based. This chapter will end with a discussion of pension plan forecasts.

\section{Actuarial Report}

Each year the plan sponsor contributes a certain amount of money to the pension fund, charges the profit and loss statement with a certain pension expense, and deducts a certain amount of money for pension costs from his taxable income. Generally, these numbers are all the same; however, that is not necessarily the case. Consequently, we shall discuss each of them separately, although they are all numbers a plan sponsor obtains from his actuarial report. We also shall discuss under separate headings each of the several measures of plan liabilities the actuary includes in his report.

\section{Contribution to the Trust}

An amount must be contributed to the pension trust each year equal to or greater than a minimum amount defined by ERISA. This amount must be contributed at some time before eight and one-half months after the close of the plan year. The actuary determines this amount using assumptions and methods that he believes are reasonable. He must certify to this each year and assumes legal liability for this certification. The IRS has promulgated regulations concerning reasonable actuarial methods. Reasonable assumptions are the legal responsibility of the actuary, although almost all actuaries consult extensively with their clients while setting assumptions. We shall discuss the exact structure of the minimum funding requirement under "Methods". Suffice it 
to say here that it is composed of a "normal cost" payment to fund current benefit accruals and a series of amortization payments to retire any current liabilities in excess of plan assets.

The plan sponsor can, of course, contribute an amount greater than the minimum. If this is done, a credit is generated in the minimum funding calculation, so that subsequently he could contribute less than the otherwise determined minimum. There are also special provisions for waiver of the minimum requirement if a plan sponsor is having financial difficulties.

\section{Pension Expense}

For purposes of determining annual earnings, a company must charge a certain amount of pension expense each year. At present, this expense must be disclosed in a footnote to the annual report to shareholders and must meet the requirements of APB Opinion No. 8. This accounting guideline again requires an actuarial calculation that yields a normal cost and an amortization payment. APB Opinion No. 8 defines a range of contributions, using the normal cost and an amortization payment that can range from a value lower than the ERISA minimum to one much higher. The critical feature here is that, once a company chooses an actuarial method and an amortization payment scheme within the allowable corridor, it must disclose any changes that occur and identify the magnitude of the cost effect of those changes. Similarly, changes in cost levels due to changes in actuarial assumptions must be disclosed.

Usually the assumptions and methods used for shareholder reporting purposes are the same as those used for minimum funding purposes. However, this is not always the case. A company's cash contribution to the trust and its charge against earnings can be different. If this is the case, the effect is reflected on the corporate balance sheet.

The Financial Accounting Standards Board (FASB) is currently reconsidering all pension accounting rules for shareholder reporting. The new rules they promulgate will replace APB Opinion No. 8 and FASB No. 36. FASB's preliminary views in this area are discussed further in Chapter $\mathrm{V}$ of this monograph. 


\section{Tax Deductible Contributions}

The IRS has defined a maximum tax-deductible contribution that can be made to a pension fund each year. This contribution once again is based on a normal cost and a series of amortization payments. The assumptions and method must be the same as those used in the determination of the ERISA minimum. The level of allowed contribution generally is substantially higher than the ERISA minimum and by definition never can be less. Although an exact definition of the maximum limit can be quite complex, it can be thought of as being no less than the normal cost plus a 10-year amortization of unfunded liabilities.

Because plan sponsors seldom wish to contribute cash to a trust that they cannot deduct on their tax returns, the corridor produced by the ERISA minimum and the IRS maximum generally serves to confine the level of cash contributions to the trust. This corridor also tends to define the limits for pension expense charged to shareholders, although this is not always the case, e.g., different methods and assumptions could be used for expense purposes under APB Opinion No. 8 and for cash contribution purposes.

\section{Actuarial Liabilities}

Many kinds of actuarial liabilities are calculated for a wide variety of purposes. To confuse things further, actuarial terminology is not well standardized in spite of several past attempts to do so. To simplify the discussion here, two general types of actuarial liabilities will be considered: plan termination liability and ongoing plan liability.

\section{Plan Termination Liability}

This liability represents the present value of all benefits that would be accrued as of the valuation date if the plan terminated on that date. Legally under ERISA, it represents the plan participants' claim on plan assets (not on the plan sponsor's assets) if the plan terminated. Accrued benefits here are usually the benefits an employee would receive if he terminated on the date of valuation and was $100 \%$ vested (occasionally, special additional plan termination benefits are also included). 
Several other liabilities very similar to the plan termination liability are probably best thought of, from the layman's point of view, as being nearly identical to the plan termination liability. These include:

\section{Actuarial Present Value of Accumulated Benefits}

This is defined in FASB No. 35 and is used as an official disclosure value on the financial statement of both the plan and the plan sponsor. It differs slightly from a pure plan termination liability in the ways it handles ancillary benefits and future turnover among nonvested employees.

2. PBGC Liability

This is the plan termination liability computed on an official set of assumptions promulgated by the PBGC. The benefits valued are divided into a set of priority categories by $P B G C$ regulations. This liability would be used in dealing with the PBGC if a plan terminated. A portion of this liability is guaranteed and represents a claim on up to $30 \%$ of the plan sponsor's net worth.

\section{Present Value of Accrued Benefits or Accrued Benefit Liability}

This is basically the name actuaries use for what the accountants have termed the actuarial present value of accumulated benefits (see 1. above).

The various plan termination liabilities are useful in that they define a market value of liabilities if proper assumptions are used. It should be borne in mind that pension liabilities do have a true market value, because insurance carriers will assume them in return for a single premium.

The plan termination liability is also a useful yardstick in defining a pension contribution strategy. For instance, one strategy might be to contribute that level percentage of pay that meets minimum funding requirements and will create a fund covering some target percentage of Plan Termination Liabilities 10 years hence. 


\section{Ongoing Plan Liability}

This is usually referred to as the actuarial accrued liability. It is that portion of the actuarial present value of all future benefits (PVFB) that is assigned by the actuarial method to the period prior to the valuation date. PVFB is the present value of all benefits accrued and unaccrued, past and future. It is a measure of the total obligations of the plan, past and future. That portion assigned to the past is called the actuarial accrued liability. (This concept will be discussed again later in the section on actuarial methods.) Due to the wide variety of actuarial methods in use, the same plan and assumptions can generate significantly different actuarial accrued liabilities. In fact, one commonly used method (Aggregate Actuarial Cost) produces a zero actuarial accrued liability by definition. It funds costs over future payrolls only.

One "theoretical" goal of all actuarial methods is to reduce the unfunded actuarial accrued liability (excess of the actuarial accrued liability over the plan assets) to zero. We stress the word "theoretical" here, because a plan close to achieving that goal would generally be considered overfunded. This is because the actuarial accrued liability includes a provision for future salary inflation and therefore usually exceeds the plan termination liability by a considerable amount, particularly when benefits are tied to final pay.

The actuarial accrued liability is such a creature of the actuarial methods and assumptions used for funding purposes that it is not a good yardstick by which to measure the funding status of a plan. It is termed an ongoing plan liability because it is part of a budgeting process whose purpose is to provide a proper flow of funds to the plan if the plan sponsor continues in business. Development of the actuarial accrued liability is part of this process but its purpose is not to provide a measure of solvency or security. It is simply a structural side effect of the budget plan. Generally, if the actuarial accrued liability is nearly fully funded, the plan sponsor should review the method and assumptions with his actuary with the intent of reducing contributions. 


\section{Other Items in an Actuarial Report}

The principal contents of an actuarial report are the values described above. In addition, a variety of exhibits usually supports the development of these items. A concise summary of the benefits valued and the actuarial methods and assumptions used is also included.

Some form of reconciliation between the prior and current year is usually provided. The level of detail varies but often a "gain and loss analysis" is done which quantifies the effect deviations from actuarial assumptions have had on the liabilities and costs of the plan since the last report. This analysis can be expanded to reconcile the pension expense values from one year to the next. The executive who wishes to understand why his pension costs change from year to year is well advised to ask his actuary to provide this type of reconciliation. A full analysis will show the impact each deviation from assumptions has on the pension expense. This gives one a good feel for the importance of each assumption and how it interrelates with other assumptions. It also can pinpoint assumptions that are significantly inaccurate.

Other miscellaneous statistics sometimes included in an actuarial report are a distribution of plan participants by age, service, sex, etc., or a projection of future pension payouts.

The next two sections discuss actuarial assumptions and methods.

\section{Actuarial Assumptions}

The selecting of actuarial assumptions for purposes of ERISA minimum funding requirements is legally the responsibility of the actuary (at least he must certify that they are reasonable). Actuarial assumptions for APB Opinion No. 8 purposes are technically the responsibility of the preparer of the financial statements but outside auditors usually would expect the actuary to render an opinion as to their reasonableness.

Although technically their responsibility, few actuaries would set assumptions without detailed consultation with the plan sponsor. Usually the plan sponsor would be involved directly in the process. Interestingly enough, outside investment advisers are 
seldom part of this process, even to consider assumptions relative to setting investment objectives. This is an unfortunate situation. Better communication here and a more thorough mutual discussion of the problems of pension funding and their interrelationship with investment strategy would make for smoother management of the plan's affairs.

One of the main reasons discussion is important relative to the setting of assumptions is that there is no one true and perfect set of assumptions for any plan. Due to the enormous uncertainties that surround most of the parameters being considered, a substantial corridor of reasonable cost and liability estimates exist for virtually any pension plan. Thus the plan sponsor and his actuary generally select an assumption set from among a range of possibilities, all of which the actuary feels comfortable with relative to the circumstances of the particular plan.

We shall discuss actuarial assumptions under three general headings: economic, demographic and other. For the most part, actuarial assumptions are simply the actuary's best estimate of what the future holds. However, some merely represent simplifying assumptions about the structure of the plan or conditions relating to the plan that make the calculations more tractable without introducing significant in accuracies.

It is very important when setting actuarial assumptions to understand the financial effect of each assumption. For instance, a detailed determination of accurate disability rates is not important if a plan's disability pension is $\$ 50$ a month payable only to totally and permanently disabled employees over age 55 with 30 years of service. On the other hand, in an airline pilots' plan, where disability benefits are often generous and disability can result from relatively minor ailments, the determination of disability rates can be a critical factor in properly estimating plan costs. We shall return to the problem of maintaining a proper perspective when setting assumptions.

The structure of actuarial assumption packages is partly a function of the technical sophistication of the calculation process. Before the widespread use of computers, actuaries used much simpler assumptions than are prevalent today. As machines become increasingly powerful and less expensive per unit of computer power, actuarial programs will grow in complexity and 
sophistication. The current state of the art in assumption setting will be discussed here, with additional comments on developments that might occur in the not too distant future.

\section{Economic Assumptions:}

\section{Return on Invested Assets}

This so-called "interest" assumption (or actuarial rate) is one that has always received a tremendous amount of attention. One reason for this is, of course, that it almost always has a major impact on cost estimates. It also tends to fascinate the layman because everyone has an opinion on what interest rates will be, whereas few people can speak intelligently on mortality and turnover rates.

The perfect in terest assumption would be the exact series of interest rates that will be earned by the plan assets over the next 70 to 80 years. The purpose, of course, is to compute the present value today of benefit payments not due for many years into the future. Traditionally, actuaries have discounted these benefit payments using a single rate of interest, thus tacitly assuming that all of the various types of assets held by the plan now and in the future will earn that rate of interest each year indefinitely in to the future. This, of course, will not be the case, but the actuary hopes that the net effect of the many different component yields being realized each year on various kinds of plan assets will average out over time to be close to his single rate assumption.

This single rate concept creates particular problems in these days of high and volatile interest rates. The actuary claims he is being very bold in assuming $8 \%$ or $9 \%$ when long-term government bonds are yielding $14 \%$. This can be very disturbing to an investment professional who is immersed in current market conditions and views history through the eyes of the Ibbotson-Sinquefield study where real returns of $7 \%$ on equities are considered a given.

This question of real returns is, of course, the first key issue relative to the actuary's interest rate judgment. Because the benefit payments under most pension plans are either explicitly or implicitly tied to inflation before and sometimes 
after retirement, an interest rate cannot be judged without considering its companion inflation assumption, discussed later under the salary assumption heading. Suffice it to say here that the interest rate judgment is a judgment on real return. The inflation judgment comes later as part of the salary assumption. The interest rate quoted in the report is, of course, the sum of the real return and the inflation assumption.

Setting a real return is no easy task. Real returns, particularly on equities, have been very volatile during the past five decades, as illustrated by the following data:

\section{Annual Total Real Return}

$\begin{array}{cccc}\text { Decade } & \text { Equities } & \begin{array}{c}\text { Long-Term } \\ \text { Bonds }\end{array} & \text { T-Bills } \\ 1930-39 & 1.9 \% & 8.9 \% & 2.6 \% \\ 1940-49 & 3.8 & -2.7 & -4.8 \\ 1950-59 & 17.2 & -1.2 & -0.3 \\ 1960-69 & 5.3 & -0.8 & 1.4 \\ 1970-79 & -1.5 & -1.0 & -1.0\end{array}$

The above pattern makes prognostications very difficult. There is certainly no definitive way to predict investment returns for the next 30 to 40 years, yet in theory this is what the actuary must do. Economic forecasters have a difficult enough time with one- to three-year projections. One possible compromise sometimes discussed is using an interest rate forecast that differs by calendar year for those years close at hand where economic forecasts are available, and then using a constant rate in the more murky distant future. This technique, though logically attractive, creates substantial difficulties for most currently used actuarial valuation programs. This roadblock could, however, be quickly overcome if plan sponsors and actuaries believe this approach to be a useful one. One of its main attractions is that it provides an interest rate assumption that relates well to currently available rates without forcing the actuary to assume that current conditions will prevail indefinitely in to the future. This technique could tie in well with the routine economic projections made by the plan sponsor as part of operating his business. 


\section{Salary Increases}

Many pension plans, particularly those designed for salaried employees, are a function of salary (e.g., final five-year average salary). This feature makes the projection of future pay levels a critical factor in estimating plan costs. Salary as. sumptions have almost as large a financial impact on cost estimates as interest assumptions. The "almost" qualification arises because salary increases do not affect cost estimates once an employee has retired or terminated from the plan, whereas interest discounts still apply.

Salary increase assumptions are generally thought of in terms of three components:

\section{a. Merit and Promotion}

Part of an employee's pay increase arises because he has acquired more experience and knowledge as part of his natural maturing process. Generally, this factor represents a rapid movement early in the employee's career followed by a gradual leveling off.

Theoretically, in a large, stable, mature employee group, this factor would have little or no effect on the aggregate payroll, as high-paid retirees would be removed at one end of the population distribution, while being replaced by lowpaid new entrants at the other end.

\section{b. Productivity}

This factor represents the average increase in value per unit of work passed on to employees in the form of wages. It would have an effect on aggregate payroll.

\section{c. Inflation}

This is the all too familiar effect of general inflation, which presumably pushes all salaries up at a roughly equal rate. This factor does, of course, have a profound effect on aggregate payroll levels.

The actuary's salary scale should be derived as the sum of these three components. Some years ago when inflation was 
low, actuaries tended to use salary scales that reflected the kind of curves that underlie the merit and promotion component noted above. As inflation started to rise rapidly, it became easier simply to assume a fixed percentage pay increase at all ages. The theoretical inaccuracy thereby introduced was small, as by this time the dominant effect was the sum of productivity and inflation, both of which are most easily represented as single percentages. Another motivating factor was the unpredictable volatility of the productivity and inflation components, which made the theoretical merit and promotion curve a somewhat academic refinement.

As noted previously, the salary scale should be judged in conjunction with the interest rate as the two are correlated in that both contain a heavy inflation component. An argument parallel to that made for interest rates could be made for setting inflation rates, i.e., set rates that vary over the next few years according to short-term economic forecasts and then level off at some ultimate level consistent with future interest projections. The pros and cons of using this approach are the same as those discussed relative to variable interest rates, i.e., programming difficulties versus consistency with plan sponsors' economic forecasts.

\section{Interrelationship of Interest and Salary Assumptions}

These two assumptions are intimately related. They both are functions of inflation. As inflation rises, theoretically both investment returns and salary increases should rise. The higher the inflation rate, the stronger this relationship tends to become. They also each have opposite effects on pension expense and liabilities, i.e., an increase in interest rate decreases pension expense and liabilities and an increase in salary scale increases them. The offsetting effect is not perfect for a variety of reasons, e.g., liabilities for retirees are unaffected by salary or inflation rates (except in the unusual case of indexed retirement benefits).

The main result of this interrelationship is that if interest and salary scales are moved up or down by the same amount, the effect on pension costs and liabilities is substantially smaller than would occur by changing the spread between them (even if one of them remains unchanged). This 
effect also tends to insulate assumptions somewhat from net losses (gains) due to swings in inflation and interest rates.

For instance, consider a plan valued assuming $7 \%$ interest and $6 \%$ salary increases where in a given year inflation goes to $10 \%$ and investment returns are $11 \%$. A large loss occurs due to salary increases in excess of the $6 \%$ rate, but this may be more than offset by the investment gain resulting from the higher than 7\% return on assets. (Naturally this offset is not very significant if the plan is severely underfunded, i.e., if it has a small asset base on which to realize the excess yield compared to a large liability on which to realize salary losses.)

This phenomenon tends to focus attention on the spread between interest and salary rates as a key measure of the degree of conservatism in actuarial assumptions. A spread of two percentage points or less (interest greater than salary) would be typical today. As interest rates move up, costs tend to drop if the spread is constant, largely due to the existence of retired liabilities as previously noted. The only problem with this whole theory is that during the past 10 to 15 years funds have not always had high returns when inflation was high. In fact, equities performed worse when inflation was high than when it was low. This whole issue, however, is more of an investment question than an actuarial one, for during those periods of high inflation, high returns have been available on alternative investments.

\section{Social Security}

Many pension plans integrate their benefit formulas with Social Security. Consequently, projections of future Social Security benefits must be made. This entails using the inflation estimate defined in the interest and salary assumptions, because Social Security benefits are indexed in several ways. Of course, the greatest force of change on Social Security benefits is legislative and no actuary has yet constructed a model to predict the whims of Congress and the body politic. 


\section{Demographic Assumptions:}

\section{Mortality}

Rates of mortality are usually taken from one of several wellknown and widely used tables. Mortality is not a particularly critical assumption in the sense that financial differences between tables in general use are small and experience seldom deviates substantially from table predictions. Contrary to popular belief, mortality rates change slowly and barring a dramatic breakthrough relative to the major killers of older people, e.g., cancer, heart disease, etc., this situation is likely to prevail in the future. The actuary generally spends little time choosing a mortality table. Usually a firm will tend to use the same table on most of its business simply to make the checking of calculations easier.

There has been much sound and fury recently about unisex mortality tables. It still is an established actuarial fact that women have significantly lower mortality rates than men. For funding purposes, sex-related tables are still generally used; in fact, the PBGC mandates the use of sex-related tables for plan termination calculations. Unisex tables are used only when mortality rates are necessary to compute benefit payments to plan participants, e:g., lump sum pension equivalents. In this area the Supreme Court has done what medical science has not been able to do: give men and women equal life expectancies.

\section{Turnover}

The prediction of rates of employee turnover can be a significant factor in estimating pension costs. The magnitude of the effect can vary considerably, depending upon the nature of the work force.

Frequently a table derived from average industrial experience is used. This simple approach is based upon the theory that the overall effect of turnover is not great relative to the uncertainty in the economic assumptions. In cases where this factor is considered more critical, the employer's turnover is studied and rates are derived based upon actual experience. Rates are usually a function of age and often a 
function of service and/or sex. The most accurate representation of reality is generally found by using rates related to age and service (so-called Select and Ultimate tables) because turnover is usually greatest among those with short service and those who are young.

\section{Disability}

In a sense disability rates are part of turnover rates but they can have a separate importance if a plan has a disability benefit. As noted previously, the magnitude of disability benefits varies widely. Where they are very significant, a special study of employee disability experience is warranted. Mortality rates among disabled plan participants also can be separately determined as they are usually significantly higher than among healthy retirees.

Disability rates themselves can be affected by general economic conditions and the magnitude of available benefits. To some extent, disability is elective, as there are a certain number of people in any active working population who could qualify for disability benefits if it was financially to their advantage.

\section{Retirement}

When a plan provides for early retirement, the distribution of peoples' ages at retirement can significantly affect cost estimates, especially if early retirement is heavily subsidized. Generally retirement rates would be derived from a company's own experience. These rates also can be significantly affected by benefit liberalizations and ad hoc company work force reduction programs.

\section{Other Assumptions:}

This is a catch-all category to cover a variety of ad hoc simplifying assumptions that frequently are made by the actuary. A large number of so-called "loads" fall into this area. For instance, if a plan has a small disability benefit, the actuary might estimate its cost on a rough basis and relate that cost to the pension costs he has computed ignoring the disability benefits. If he finds it represents $2 \%$ of the total, he might simply assume for all future valua- 
tions that the cost of that benefit is best estimated by simply increasing (or loading) the pension cost by $2 \%$.

Other types of ad hoc assumptions might include ones relating to imperfect census data. If a plan provided for a benefit prior to $1 / 1 / 78$ based on average pay for the years 1974 to 1978 , it is quite possible the company would be unable to provide pay histories without considerable effort. Consequently, the actuary might estimate a pay history by projecting current pay backward using an assumed salary scale. Many situations like this require selective ingenuity. Ironically, after considerable analytical effort on the part of the actuary and the plan sponsor in choosing a set of assumptions, the only thing they can be sure of is that the assumptions will not be met. It is, of course, the earnest hope of all involved that the various errors will be offsetting and that over time the chosen assumptions will produce an accurate net result.

Assumptions can be tracked using an actuarial gain and loss analysis by source, which will evaluate the impact that experience deviations from the assumptions have on the magnitude of cost and liability estimates. These analyses are useful both in putting these deviations in financial perspective and indicating the degree to which they offset one another, e.g., large investment gains are frequently offset by salary increase losses as would be expected if inflation spurts ahead of projections. Demographic assumptions also can be studied directly and individual rates tested. For instance, a turnover study might show that even though turnover gains and losses were small, the rates used for young people were too high and those for older employees too low. As actuarial programs become more sophisticated, detailed gain and loss analyses and demographic studies may become a routine by-product of the valuation process.

One of the more recent innovations in actuarial projections is the use of stochastic modeling. This process simply means that instead of assuming interest rates will be $\mathrm{X} \%$ for all years into the future, it is assumed they will have a mean value of $\mathrm{X} \%$ but they will be randomly distributed around $\mathrm{X} \%$ with a standard deviation of $\mathrm{Y} \%$. The assumptions can become even more complex as interest rates can be set by asset class and correlations can be assumed between inflation and equity performance, between $T$. Bills and inflation, etc. These models have not been proposed to produce official valuation results but have been extensively used 
to test valuation assumptions under different scenarios. One point they clearly bring home is that an actuarial cost estimate should really be stated as a mean cost with a standard deviation corridor around it, e.g., a pension expense of $\$ \mathrm{X}$ million plus or minus $\$ Y$ million.

It is extremely important when interpreting actuarial values to bear this in mind. No physical scientist would ever quote estimates without stating his margin of error. Unfortunately, actuaries have not historically done this, and it frequently leads people to focus on ridiculous issues. For instance, if 70 retirees were inadvertently left out of the employee data on a large plan with, say 3,000 retirees, the plan's cost might be understated by $\$ 1$ million. An excited auditor discovering this error comes rushing to the actuary and the plan sponsor noting a $\$ 1$ million underpayment. Yet in a plan of this size (say, $\$ 70$ million in annual contributions) the range of possible costs due to the uncertainty in the spread between the interest and salary assumption (let us say, plus or minus $1 \%$ ) could create an uncertainty in the cost estimate of plus or minus $\$ 20$ million. This uncertainty, when not properly understood, can create great disquietudes in the souls of men who are used to determining costs by adding up the bills paid. Unfortunately, there is no way to define away this uncertainty. It is inherent in the nature of the economic world.

Ironically, even stochastic techniques, i.e., techniques that provide a theoretical framework for quantifying uncertainty, have some substantial shortcomings. They are truly useful only when the means, standard deviations, and shapes of the mathematical distributions of expected investment returns are known. In the area of long-range economic forecasting, there is no evidence to show that we have any real feel for these parameters. The actuary's traditional models (deterministic as opposed to stochastic because they assume determined values for the future) probably are still reasonable ways to cope with the vagaries of the future. They are at least considerably easier for the layman to understand than stochastic developments. To understand and be able to draw intelligent conclusions from a stochastic presentation requires substantial knowledge of the underlying mathematics. A key problem in presenting the results of one of these studies is to express the qualifications correctly to one's audience so the presentation can be professional. Too often results are expressed as, "Your pension costs will be no greater than $\$ \mathrm{X}$ or less than $\$ \mathrm{Y} 10$ years 
hence at a 90\% confidence level." What is not discussed is what confidence one should have in the confidence level. It, like many things in these calculations, is predicated on a series of somewhat speculative assumptions.

Stochastic modeling may ultimately be the best approach to valuation work, but it needs further development before replacing traditional, deterministic techniques.

A final point to bear in mind relative to actuarial assumptions is that they are chosen with the expectation they will have to be reviewed periodically and probably will be changed. Each plan sponsor should have at least a short discussion with his actuary every year concerning the appropriateness of his assumptions. Every three to five years a more in-depth investigation (with the investment manager included) would be good practice. In these stormy economic seas, mid-course corrections are the only practical way to keep the ship pointed in the right direction.

\section{Actuarial Methods}

Actuarial methods are plans by which to budget the payment of future pension benefits. Three major methods (and one variation on a method) are in common usage today. The general objective of all these methods is to accumulate for each employee on his retirement date a fund equal to the present value of his future pension payments at that time. Thus, when an employee retires, the company would have fully funded its obligations to him.

In order to understand how the various actuarial methods accomplish this goal a good place to begin is to define the total pension liability for all benefits accrued and unaccrued, past and future. This liability is generally termed the present value of all future benefits (PVFB). PVFB is the single sum of money that, if it were in the trust and if the actuarial assumptions all worked out, would pay for all benefits to the current employee and retiree population.

Bear in mind "all benefits" here includes benefits not yet accrued; therefore, it would be inappropriate actually to have this sum on hand. Some portion of PVFB should be on hand in the trust, and the remainder should be funded over future years in a manner defined by the actuarial method. If PVFB were cov- 
ered by assets in hand, it would imply that the current generation of shareholders had been charged for benefits not to be earned until some future period. Such a process would be unsatisfactory both in terms of Generally Accepted Accounting Principles (GAAP) and IRS tax practices. It also should be noted that PVFB refers only to current employees and retirees.

This closed-group concept ignores future hires. The only methods acceptable to the IRS at this time are closed-group methods. Open-group methods (i.e., projecting new hires) are occasionally used for purposes of special long-range planning studies but they are currently unacceptable for tax and accounting purposes.

The selection of an actuarial method for ERISA purposes (minimum funding) is the responsibility of the plan sponsor and his actuary. The IRS has certain prescribed rules regarding the acceptability of methods for this purpose. The IRS must also approve any change in method, although there is an automatic approval process for the standard methods. For pension expense purposes, the plan sponsor must choose a method based on rules in APB Opinion No. 8. The Financial Accounting Standards Board is currently rethinking this whole area and we expect fairly significant changes in the not too distant future. Those changes may include a strict definition of a single actuarial method for GAAP purposes.

The variations in actuarial methods generally revolve around how they budget the funding of the difference between PVFB and the trust assets on the valuation date. The three methods to be discussed here are the Entry Age Normal Method, the Aggregate Cost Method and the Unit Credit (or Accrued Benefit) Method. A variation on the Aggregate Cost Method called Frozen Initial Liability also will be discussed together with the Term Cost Method, which is used sometimes for ancillary benefits (disability, death, etc.). Finally, we shall treat asset valuation techniques under a separate heading.

Each actuarial method derives something called a "normal cost". The old joke is that it is neither "normal" nor a "cost". It is instead simply what the actuarial method assigns as the amount to fund current benefit accruals. For certain methods the relationship to current benefit accruals is very tenuous. Two of the methods ascribe to years prior to the valuation date a part of PVFB called 
the actuarial accrued liability. The actuarial accrued liability was discussed earlier under the heading "Ongoing Plan Liability." The excess of this actuarial accrued liability over plan assets is called the unfunded actuarial accrued liability. It gradually becomes funded via a series of amortization payments.

\section{Entry Age Normal Method}

This method proceeds by determining for each employee his share of the PVFB and then calculating the level percentage of his pay necessary to fund his PVFB if it were paid from his date of entry to the plan until his retirement date. For instance, if the company put an amount into the trust equal to $5 \%$ of Smith's pay from the time he joined the plan in 1960 until the time he retires in the year 2000, and if that amount plus interest was exactly equal to the amount necessary to fund the pension he would be entitled to in 2000 , then $5 \%$ would be his correct normal cost percentage. If he were earning $\$ 20,000$ in the current year, his normal cost would be $\$ 1,000(5 \%$ of $\$ 20,000)$. If the actuary assumed a $6 \%$ salary scale, Smith's next year's normal cost would be $\$ 1,060(5 \%$ of $\$ 20,000$ plus a $6 \%$ pay increase).

This method is called the Entry Age Normal Method because the $5 \%$ is sufficient only if paid from entry age. In fact, most plans grant benefits for employee service prior to plan inception. Consequently, the normal costs from an employee's entry to the date of plan installation would not have been paid. This shortfall is generally what creates the unfunded actuarial accrued liability in the Entry Age Normal Method. The unfunded actuarial accrued liability is calculated by subtracting from PVFB the assets on hand and the present value of future normal costs. This leaves the unfunded actuarial accrued liability as a balancing item. In actuality, it is composed of more than just a provision for benefits accrued before the installation of the plan. It also includes the effects of plan amendments, some of which may have granted additional benefits for past service, and the effects of actuarial gains and losses, i.e., deviations of experience from actuarial assumptions.

The unfunded actuarial accrued liability is retired over time by a level-dollar amount amortization payment. This pay- 
ment is computed like a mortgage amortization payment, i.e., with interest, not like a straight line amortization. The total pension charge, then, is the sum of the normal cost plus the amortization payment; therefore, only part of the total charge is a level percentage of payroll (normal cost). This implies that if the amortization payment is a significant part of the total charge and if payroll is increasing at a reasonably fast rate, the total charge will decline as a percentage of payroll over time.

There is nothing sacred about a level percentage of payroll charge but it is very common to think of pension expense as a labor cost and hence directly related to payroll. Many negotiated plans are not salary-related, so costs developed for them tend to be done on a level-dollar basis rather than as a percentage of payroll. This is a very problematical area as these plans are periodically renegotiated at higher benefit levels; thus, in the end they behave like pay-related plans even though they are not.

The determination of amortization periods is a complex issue. Under APB Opinion No. 8, for pension expense purposes plan sponsors can use anything from in terest only (an infinite amortization period) to 10-year amortization. The variations are almost endless. We shall describe here the hierarchy of amortization levels defined by ERISA for minimum funding purposes. A somewhat similar structure of bases is used to compute the maximum tax-deductible limit; pension expense systems are frequently similarly complex.

ERISA states that:

a. The unfunded actuarial accrued liability as of $1 / 1 / 76$ or plan inception should be funded over:

- $\quad 40$ years for plans in effect on or before $1 / 1 / 74$.

- 30 years for plans started after $1 / 1 / 74$. 
b. The increase (or decrease) in unfunded actuarial accrued liability due to:

- Plan changes should be funded over 30 years from the date of plan change.

- Assumption changes should be funded over 30 years from the date of assumption change.

- Actuarial gains and losses should be funded over 15 years from the date they occur.

This type of scheme gradually leads to a long schedule of pieces of liabilities, each being amortized over its designated period. The total amortization payment is, of course, the sum of these pieces. The objective of the exercise is to get all of the actuarial liability funded by some point in the future.

\section{Aggregate Cost Method}

This method generates no unfunded liability. It simply derives a normal cost percentage by dividing PVFB less the plan assets by the present value of all future salaries for all current employees. This aggregate normal cost percentage is then applied to the total payroll each year to obtain that year's normal cost.

This method is very simple in the sense that it eliminates specific calculations for gains and losses, schedules of amortization payments, etc. It does lack some flexibility because, since there is no actuarial accrued liability generated, the IRS tax maximum and ERISA minimum contribution levels are the same. It also frequently produces a higher cost than other methods because it effectively spreads the unfunded PVFB over a fairly short time span (average future payroll years).

A commonly used variation on this method is called the Frozen Initial Liability Method. Under this method, in a plan's first year an unfunded actuarial accrued liability is calculated on either the Entry Age Normal Method or the Unit Credit Method. This amount is then frozen (the Frozen Initial Liability) and amortized over a fixed period 
of years. In future years, calculations are made on the aggregate method but the normal cost percentage covers PVFB less the assets and less the unamortized portion of the Frozen Initial Liability. The amortization of the Frozen Initial Liability creates a corridor between the IRS tax maximum and the ERISA minimum.

\section{Unit Credit (Accrued Benefit) Method}

Under this method the benefits to be paid to an employee at retirement are divided into three pieces:

a. A portion attributed to service prior to the valuation date.

b. A portion to be earned during the year following the valuation date.

c. A portion to be earned between one year after the valuation date and retirement.

The present value of "a" above is deemed to be the actuarial accrued liability and the present value of " $b$ " above is deemed to be the normal cost. The exact method of determining $a, b$, and $c$ above varies depending on the plan provisions. In some simple plans not based on final pay, "a" is just the benefit actually accrued to date, i.e., an employee's benefit entitlement if he were $100 \%$ vested (hence the term accrued benefit method). Item " $b$ " then is simply the estimated increase in "a" during the next year. In final pay and other more complex plans the determination is somewhat more artificial. The simplest technique in these instances is to prorate by service, e.g., if a 50-year old had 10 years of past service and was to retire at 65 , "a" would be $10 / 25$ of the total, "b" $1 / 25$ and "c" $14 / 25$.

The Unit Credit Method is most commonly used among nonpay-related negotiated plans. However, it has come into somewhat greater use for salary-related plans in recent years. It generally produces somewhat lower current costs, particularly for a young group. This implies a deferral of cost into the future, as in the end all methods must meet the same objective. Thus costs under this method tend to 
escalate, particularly if a young stable group gradually becomes an old, stable group. FASB, in its published Preliminary Views, favors requiring the use of the unit credit method (prorating for service as noted above). If they prevail in this view, this method will probably become the standard used by most plans subject to their rules.

\section{Term Cost Method}

Sometimes in order to simplify calculations of costs on ancillary benefits, actuaries use the Term Cost Method to value these benefits. This is particularly true when the ancillaries are not a large part of the total cost. This technique is gradually falling into disfavor because of IRS pressures and the availability of more sophisticated computer programs, but it is still used fairly extensively. Under this method the actuary would simply estimate the probability that an event, say disability, would occur for an employee in the following year. That probability times the present value of the disability benefit he would receive would become the normal cost for that employee. This process thus provides the actuarial cost of the benefit for that one-year period in the same fashion as a one-year term insurance policy. If no one were eligible for a disability benefit in a given year, no cost would be generated. This means no prefunding occurs. This lack of prefunding and certain other technical defects create no significant problems as long as the ancillary benefit is small in value relative to the pension benefit. However, when this is not true the ancillary should be valued as part of the regular method used for the pension benefit.

In the foregoing discussion of ERISA minimums we did not allude to a special provision called the Alternative Minimum. This is a technique that can be used to limit the funding requirement to the increase in the unit credit actuarial liability even though another method may be in use. Without going into all of the details here, suffice it to say that if a plan sponsor is interested in temporarily reducing his funding requirement, this is one of several approaches he should investigate with his actuary. 


\section{Asset Valuation Methods}

There are two traditional ways to value pension plan assets, i.e., market value and book value (cost). The actuary has always been skeptical about using market value due to the frequency of large short-term swings in security prices. In order to use market value properly, the actuary should value the liabilities at market also, which implies changing the interest rate assumption each year to meet the changing condition of the securities marketplace. This approach is, in fact, what is encouraged by FASB No. 35, which requires market value of assets to be used for disclosure purposes. There is an illusion of accuracy connected with market values because of the assumption that securities could be converted to cash at published prices. In fact, it is questionable whether any large fund could be liquidated with rapidity and if many tried to do so simultaneously, the entire securities market would collapse.

Nonetheless many funds use market values without changing interest rates annually and accept the cost impact of market fluctuations. These fluctuations cause actuarial gains and losses in the sense that they create a deviation from the actuarially assumed interest rate. This gain or loss is an increase or decrease in actuarial liability that is amortized over time for cost purposes (usually 15 years as in the ERISA minimum).

Other plan sponsors and their actuaries seek the relief of some different way of valuing assets. Pre-ERISA assets were frequently valued at book, which tended to provide some smoothing of the worst market fluctuations. ERISA required that all asset valuation methods be related to market, thus excluding a pure book approach. ERISA did provide a statutory exception in that bonds may be valued at book adjusted by amortizing premiums or discounts (as long as all bonds are so valued).

Of course, many other ways are available to smooth out asset values that do involve market value. Several common methods are described below:

\section{Book-Market Weighted Average}

A weighted average of book and market could be used. For instance, if 50-50 weights were employed, a formula value of assets halfway between book and market would be obtained. 


\section{Average Ratio}

The arithmetic average of the last few years' ratio of market to book could be applied to the current year's book to obtain a formula value.

\section{Expected-Actual Weighted Average}

Here a weighted average of the expected assets and the actual market value is used as the formula value. The expected assets are last year's formula assets plus cash flow, all brought forward at the actuarial assumed rate.

The number of possible methods is infinite as it is only limited by the imagination of actuaries and plan sponsors. The IRS, becoming concerned about this unlimited latitude, felt that rather than try to specify acceptable techniques they would simply require consistency of approach and place a constraint on the end result. The constraint is that no method can produce an asset value greater than $120 \%$ of market value nor less than $80 \%$ of market value. In its Preliminary Views the FASB favors requiring the use of market values for its purposes. If this position is finalized most plans subject to FASB rules will probably use market value rather than any smoothing formula.

This presents a potential problem because without the use of a smoothing technique, some plan sponsors may be tempted to concentrate investments in less volatile assets, thereby foregoing higher returns available over time from more volatile investments. Given the long-run nature of a pension plan, foregoing such return opportunities may result in unnecessary costs to the company.

\section{Pension Plan Forecast Studies}

A pension plan forecast is a projection into the future of some of the various financial measures used to describe the plan, e.g., employer contributions, actuarial liabilities, retirement benefits, etc. There are various types of forecasts depending on the plan sponsor's interest and purpose. The following discusses some of these varieties. 
1. Forecast Valuations-It is theoretically possible to actually value a pension plan using forecast techniques. Thus there are forecast valuation methods in the same sense that there are entry age normal or unit credit valuation methods. In actual practice such methods are seldom used, since they are not recognized by the IRS as legitimate methods for purposes of ERISA minimum funding rules or tax deductibility. The major stumbling block in this area is how to deal with new entrants in the valuation process.

2. Supplemental Forecasts-As a routine part of an actuarial valuation some forecasting is frequently done. For instance, a 10 -year forecast of pension payouts is a standard feature of many valuations. In addition, where more elaborate preparations have been made, other items can be projected, e.g., active and inactive employee groups, future normal costs, and future actuarial liabilities.

3. Investigative Forecasts - In some situations, forecasts are undertaken without specific goals in mind but more as an investigative project to see what the future might hold. The objective is to see if there are any unanticipated problems that can be headed off or at least prepared for.

4. Forecasts for Specific Purposes-The most common type of forecast is that undertaken to answer one or more specific questions management has raised. Frequent questions include:

a. Size of unfunded liabilities in the future, e.g., unfunded actuarial liabilities, unfunded accrued benefit liabilities, or unfunded vested benefit liabilities. This question often evolves from the disclosure requirements in company financial statements.

b. Sensitivity of contribution and unfunded liability levels to asset movement. In particular, different investment strategies and future market scenarios are usually tested. Setting a funding policy is often an objective in this type of study. The results of the study can then be used to discuss the funding policy and its rationale with the plan's investment advisers. 
c. Project cash flow patterns for the fund. This can include projections of both externally generated cash flows, e.g., employer contributions and pension payments, and internally generated flows, e.g., stock dividends, bond coupons, and portfolio turnover. This type of projection would also frequently be used in setting funding policy because it estimates future liquidity needs.

d. Sensitivity of contributions and unfunded liabilities to various demographic changes, e.g., massive layoffs, plant closings, large-scale hiring programs, etc. Particular attention here might be given to possible PBGC liabilities and liens that might arise in the event of a plan termination (full or partial).

e. Test different actuarial assumptions. The variation in employer contributions and liabilities that would occur under different sets of actuarial assumptions would be tested against various experience scenarios. The objective would be to set actuarial assumptions that produce the most sensible pattern of gains and losses, given the future scenarios most likely to occur. Asset valuation methods are also often tested this way.

f. Test different contribution strategies. Examine funding progress under varying company contribution strategies from minimum ERISA levels up to the maximum tax-deductible limit. This type of study could also project levels of internal book reserves if the company does not intend to change pension expense at the same rate it is contributing cash to the trust.

g. Test different union negotiation strategies. The impact on company contributions and plan benefits of different levels of benefits settled on in future negotiation can be projected. The related effect on salaried and other company plans can also be looked at. 


\section{CHAPTER V}

\section{ADDITIONAL PERSPECTIVES ON PENSION PLANS}

In the past several years, several new issues regarding defined benefit plans have caused considerable discussion. These issues include a different way to view these plans, alternative investment strategies, appropriate portfolio investments, and accounting treatment.

\section{A Different Point of View of Pension Plans}

Before ERISA, Jack Treynor, then editor of the Financial Analysts Journal, presented a point of view suggesting that a corporation's financial condition should be viewed in terms of an augmented balance sheet, with the pension fund assets listed among the corporation's assets and the pension liabilities added to the corporate liabilities. All of these assets and liabilities would be valued at market.

The rate at which the future stream of pension liabilities is discounted is critical, and Treynor suggested that the appropriate discount rate should be the riskless interest rate. If the corporation does not have an obligation to protect the beneficiaries against inflation, the discount rate should be the rate on the riskless (i.e., U.S. government) securities of maturities comparable to the obligations of the plan. If the corporation has an obligation to protect the beneficiaries against the effects of inflation, the discount rate should be the real rate of interest, i.e., the riskless rate with inflationary expectations removed. This rate is generally assumed to be about $3 \%$.

Any corporation that appears insolvent on this basis is passing risks on to the plan beneficiaries, because corporate assets are not adequate to cover liabilities, including pension liabilities. Plan beneficiaries also bear the investment risk when plan assets are invested in other than riskless securities.

After the passage of ERISA, this view was reviewed and revised. The contractual value of the pension claim of the employees was computed as described above. This value was distinguished from the economic value of the claim. Because claims are not due for a 
long period of time and the availability of funds to pay these benefits is uncertain, the economic value is always less than the contractual value calculated at the riskless rate. The difference between these two values is called a "pension put," and prior to ERISA this "put" was equivalent to an option held by the shareholders to pay less than the full benefits promised in the plan. Therefore, the "put" could be listed as a corporate asset on the augmented balance sheet.

ERISA eliminated the "pension put" for most corporations. Legally, if a plan's unfunded liability grows dangerously large, the PBGC can terminate the plan and seize the assets as well as up to $30 \%$ of the corporation's net worth to pay the beneficiaries. If the PBGC permits a corporation's unfunded guaranteed benefits to grow to more than $30 \%$ of its net worth, the corporation does have a "pension put," but it is now against PBGC and not against the beneficiaries.

\section{Alternative Investment Strategies}

Flowing from the analysis in the previous section, several articles in the professional literature of the past several years, primarily associated with Fischer Black and Irwin Tepper, recommended a different strategy for pension fund investment. They reason that, although legally the pension fund belongs to the beneficiaries and is to be run solely in their best interests, the beneficiaries in fact have little concern about the investment results or funding status of the plan. If assets are inadequate to pay benefits, the beneficiaries have a direct claim against the company as well as the insurance benefits provided by PBGC. Shareholders of the corporation, on the other hand, have a major interest in the pension fund, because fund investment results have a significant impact on corporate contributions and therefore corporate profits. Therefore, pension fund assets should be considered just as other corporate assets.

The second part of this thesis is that the pension fund has the advantage of favorable tax treatment. The earnings of the fund are not taxed if they are used to pay benefits. Consequently, the corporation should seek investments where pretax and after-tax rates of return are significantly different. From the shareholders' point of view, the most advantageous investment policy would be the following: 
1. Sell the stocks held in the pension fund and invest the fund entirely in bonds of the same quality as the sponsor corporation's own bonds. The interest income on the purchased bonds is tax-free.

2. Have the sponsor corporation sell bonds and use the proceeds to fund the pension plan fully. The interest payments on these bonds are tax-deductible.

3. From the corporate shareholder's point of view, the amount previously held in stocks in the pension plan can be invested more advantageously within the sponsor corporation itself. Alternatively, the amount held in stock could be used to repurchase the corporation's shares.

The benefit of this process to the shareholder is that, although his position in the company is not affected, the corporation has raised money through bonds where the interest cost is roughly halved by the corporate tax rate and invested it in similar securities where the interest income is entirely tax-free.

Although widely discussed, no major change in pension fund investment practices has been observed as a result of this work. Such a step would be contrary to current accounting conventions, where specific assets are not offset against specific liabilities on the balance sheet. The reason most often cited is a legal one: the pension fund is perceived as an entity separate from the corporation to be run solely in the interests of the beneficiaries. Corporate officers are reluctant to approve investment changes that might be considered not properly diversified, atypical, and for the primary benefit of the shareholders. In addition, the income on the bonds in the pension fund can be used only to pay benefits and is not available for other corporate purposes.

In the final analysis, the major loser in this process is the federal government through reduced tax revenues. Should the proposal be adopted widely, some further changes in the Internal Revenue Code or in pension fund legislation could well occur.

Tepper recently has argued that, in theory, the optimal way to secure benefits is to establish more stringent funding practices. 
However, he believes this development is not likely and that, within a decade, pension assets and liabilities will be placed directly on the sponsor's balance sheet. If this happens, he contends the projected growth of pension fund assets will be significantly curtailed; contributions to fund the plan would no longer be necessary because the plan benefits are clearly a corporate liability payable from corporate assets. No impact on the market value of the company's stock is foreseen, however, because in an efficient market with full disclosure, the condition of the pension fund as well as the condition of the corporation are known and reflected in the market price. As will be discussed in the next section, within the next few years the Financial Accounting Standards Board probably will require that the net pension liability be placed on the balance sheet. However, it seems extremely unlikely that the ERISA requirements for minimum funding will be abolished.

\section{Accounting Treatment}

In addition to the various methods of valuing plan assets and liabilities that are used by the actuary and the economic valuation suggested by Treynor, another approach is being taken by the accounting profession.

Before 1966, many different methods were used to account for pension costs. At that time, the Accounting Principles Board issued APB Opinion No. 8, which requires a corporation to reflect on its books a pension charge at least equal to the normal cost of the plan plus interest on the corporation's unfunded actuarial accrued liability. However, unfunded liabilities did not have to appear on balance sheets unless required accruals had not been funded.

The next official statement by the accounting profession was made in 1980, when the FASB issued Statement No. 35, Accounting and Reporting by Defined Benefit Pension Plans, and Statement No. 36, Disclosure of Pension Information. These interim measures are to be used pending completion of a major study on the subject and a final determination by the FASB. Statement No. 35 deals with the financial statements of the pension plan and Statement No. 36 covers the disclosure requirements on employers' financial statements. 
Statement No. 35 specifies how the present value of the benefits is to be determined. The unit credit method is to be used uniformly in computing the present value, because the entry age normal method, which is the actuarial method used in most pension plans, causes costs to be charged before they accrue. Consequently, future salary increases and future years of service are not considered, which some analysts argue results in an underestimate of future liabilities. Plan assets are to be evaluated at fair market value.

Statement No. 36 requires all corporations to disclose in a balance sheet footnote the actuarial present value of all accumulated plan benefits and the market value of plan assets available to pay these benefits. In addition, the assumed rate of return on the plan's assets and the date on which the benefit information was based must be disclosed. Finally, any changes in actuarial cost method, actuarial assumptions or plan provisions that affect the comparability of reported data from one period to another must be indicated.

The FASB continues to study the feasibility of putting pensionrelated items on the plan sponsor's balance sheet, and in November 1982 the FASB published Preliminary Views of the Financial Accounting Standards Board on Major Issues Related to Employers' Accounting for Pensions and Other Postemployment Benefits. This report covers only single-employer, noninsured defined benefit plans in the United States. Other rulings covering other types of plans will be issued later, but the report does provide a good indication of the Board's thinking. After further study and hearings, an Exposure Draft on this subject may be issued in 1983 and a final statement in 1984 or later.

The significant elements of this report are:

1. The net pension liability (or asset, if that is the case) will be shown directly on the balance sheet.

2. The net pension liability is equal to the net of:

a. The pension benefit obligation

b. Less the plan's net assets 
c. Plus or minus the Unamortized Measurement Valuation Allowance.

(Although netted out on the balance sheet, each of these items will be identified in a footnote.)

3. The pension benefit obligation is:

a. The actuarial present value of the benefits attributable to employee service up to the date of the financial statement, increased by an estimate of future compensation increases.

b. The assumed rate of return on the plan's assets is determined as currently under FASB No. 35.

4. The pension plan assets will be evaluated as under FASB No. 35, i.e., at fair value, which, for marketable assets, will be market value.

5. The Measurement Valuation Allowance (MVA) is used to recognize changes in the pension benefit obligation due to:

a. Actuarial gains and losses, i.e., plan experience different from the actuary's assumptions. This would include net appreciation or depreciation in the value of the plan's assets different from the assumed rate of return.

b. Changes in actuarial assumptions.

Initially, the MVA will be equal to zero.

6. The Intangible Asset (IA) is to be shown as a separate item on the balance sheet.

a. If a new plan or an amendment to an existing plan results in benefits (and therefore plan liabilities) due to employee prior service, this offsetting asset is created and amortized over future periods. 
7. MVA and IA Amortization.

a. The annual amortization of these two items is a percentage of the unamortized balance equal to 100 divided by the average remaining service period of active plan participants. For example, if the average remaining service period is 25 years, the amortization would be 100 divided by 25 , or $4 \%$. The amortization rate, therefore, accelerates as the labor force ages.

8. In the first year, existing plans may do one of two things:

a. Deduct the total net pension liability less any unamortized intangible asset from retained earnings; net worth may be reduced substantially but future annual earnings will not be penalized.

b. Set up an Intangible Asset equal to the pension liability and amortize it; future annual earnings will be lower but the charge to retained earnings will be spread out.

9. In addition, financial statements or footnotes must disclose the following:

a. General description of the plan

b. Components of pension liability

c. The unamortized balance of the IA and the amortization rate applied to the IA and the MVA

d. Assumed rate of interest

e. Compensation increase rate assumed

f. Funding policy

g. Annual contribution 

h. Effect of significant changes affecting comparabil- ity of the data.

10. The Annual Pension Cost would be the sum of changes in the net pension liability and in the intangible asset, excluding decreases in the net pension liability that result from employer contributions.

These decisions are tentative, controversial and may be changed. However, some observations can be made:

1. The net pension liability will be reflected on the balance sheet, not just reported in a footnote. All liabilities will be included, not just vested liabilities. At the outset, these liabilities either will be charged against retained earnings or amortized against annual earnings; in either case, the capital structure and the future earnings growth of the company will be affected.

2. The annual pension expense will be the change in the pension liability. Companies will not be able to vary the pension expense, only the amount of the annual contribution (with its associated impact on income taxes paid).

3. A uniform method for estimating pension liabilities will be required for accounting purposes, which may or may not be the same as the funding method currently used by the company for actuarial purposes. Companies that use the entry age normal method, which takes future service and salary increases in to account, could find their plans overfunded under the new method.

4. The age of the labor force will have a very important impact on a company's financial statements. The median age of active plan participants, according to Greenwich Research Associates, is about 40 years, indicating that the average amortization period would be about 20 years. However, the average age of plan participants varies substantially among companies. Greenwich Research Associates also indicates that the median number of years used to amortize unfunded 
pension obligations is about 30 , and this number does not vary substantially by company. Some effects may be as follows:

a. For many companies, the amortization period will be shortened for accounting purposes. It is even possible that the resulting pension expense could be more than the maximum contribution allowed by the IRS.

b. For many companies with a relatively young labor force, the cost of pensions each year will increase as average age moves up.

c. Using market value to evaluate most plan assets will cause greater volatility than using the smoothing techniques adopted by many actuaries. This volatility will be reflected in changes in the MVA, but the earnings impact through MVA amortization will be a function of the age of the labor force.

5. Should greater volatility be introduced in to the valuation of assets, the company might choose to invest the pension fund portfolio in more stable assets, thus foregoing the greater return over time that may be available from alternative assets.

6. Analysts and debt-rating agencies may view the MVA and IA as intangible assets like good will and deduct them from retained earnings. If this occurs, the impact upon annual earnings and balance sheet ratios could be substantial.

7. Assumptions about the rate of future salary increases will have to be disclosed and will have to be consistent with the actuarial assumptions. Management is not likely to be pleased with the requirement to show projections of salary increases.

8. Because the plan liability includes estimates of the cost of future salary increases, companies may wish to terminate their defined benefit plans and switch to 
defined contribution plans. Defined contribution plans ordinarily are more conservative in their investments and prefer limiting volatility to seeking higher returns.

These changes are far reaching, and it is difficult at this writing to assess all their implications. At a minimum, senior corporate executives will focus on pension plans as never before, because the bottom-line impact on the corporation's earnings and on stock values, bonus plans and incentive stock options could be significant. Greater uniformity of reporting for accounting purposes will have been achieved. However, changes in employee benefit patterns and their related costs could be significant, and some analysts will contend that none of the procedures adopted accurately reflects the value of the pension plan or its costs to the company. 


\section{CHAPTER VI}

\section{SOME MYTHS ABOUT PENSION FUNDS}

Over a period of years, it is inevitable that a certain folklore would evolve regarding pension plans and their administration. These myths most often are articulated by the plan sponsor, but the investment manager and others have been known to hold them also. In the light of the material covered thus far, it may be useful to examine some of these myths and put them in some perspective.

\section{The investment manager should try to meet the actuarial rate.}

It is not the actuary's job to set goals for the investment manager. The plan sponsor and the investment manager should set those goals based on considerations such as risk, liquidity needs, market forecasts, economic conditions, etc. The actuary should then use these goals as part of his rate-setting process. Because the actuary's time horizon is significantly longer than that used in setting investment goals for the investment adviser, the actuarial rate would be an improper goal in any event. More important, however, is the concept that the investment adviser following the actuary's lead is the tail wagging the dog. The investment adviser is the expert in near-term investment prognostication, not the actuary. It could, however, be very useful to involve the actuary in the discussions of overall investment goals so that the interest rate used harmonizes well with the established investment goals.

\section{Our annual contribution more than covers benefit payments, so we don't need to worry about asset allocation.}

The first part of this statement is very often true, especially if the plan participants are young and the ratio of active to retired employees is very high. However, the statement seems to imply that contributions are a function of current benefit payments and that, so long as contributions cover benefit payments, a disciplined process to review and perhaps adjust the asset mix in the light of established investment objectives is unnecessary. Many companies that rushed to invest in long-term fixed-income contracts in 1974 gave up substantial incremental returns available 
in subsequent years. However, contributions are more related to the actuarial soundness of the plan, the variance in the actuarial assumptions from experience, and the costs the company can tolerate. Asset allocation is a process undertaken after investment objectives have been set; it is designed to review alternative asset mixes in order to establish the one best suited for the client's return desires and risk tolerance. Ignoring this part of the investment process just because benefit payments are covered by current contributions could lead to trouble in the future.

3. We invest our plan assets in a fixed-income contract to insure benefit payments at a rate higher than our actuarial rate-it's a conservative thing to do.

The primary problem with this approach is the risk of being locked up for a long time with a fixed investment return in an inflationary environment when interest rates are very volatile. The return, which may seem attractive at the moment, could well be below those available from alternative investments at some future time. Moreover, meeting or exceeding the actuarial rate alone doesn't assure the soundness of the plan's funding. Subsequent changes in plan provisions or significant departures from actuarial assumptions could add to costs. In addition, these fixedrates contracts assume the soundness of the insurance company, for the contracts are, in effect, unsecured obligations of the borrower. Given the difficulties of predicting the longer-term future, the loss of flexibility associated with this approach can be a serious problem, not to mention the problem of dealing with inflationary surprises.

4. We have invested in a dedicated bond portfolio, where the maturities match our retired-lives liabilities. The actuary has assumed a higher interest rate on this pool of liabilities, thus reducing our costs of funding the plan.

Isolating a batch of liabilities, giving them a label and matching this pool of liabilities with a dedicated portfolio may reduce costs on a near-term basis, but it also may fail to recognize the returns available from the total capital markets. As we suggested in the portion of this manuscript on liability partitioning, the portfolio may be divided into portions that have different investment risk and return objectives, but the assumed investment returns used by both the actuary and the investment manager for the total 
portfolio should be logically consistent with each other and with the returns that seem reasonable for the capital markets as a whole.

Investing in a dedicated bond portfolio only reduces the cost of the plan if there are no other available investments with a higher return. Of course, the reduction of uncertainty is important. The actuary and the plan sponsor often feel more comfortable adjusting the actuarially budgeted cost when a dedicated bond portfolio is used because the return is more of a "sure thing" than the potentially higher return on equities. However, such a step may reflect more their sense of fiduciary responsibility than their evaluation of investment potential. Equities could still produce higher returns over time. It is a matter to be decided only after full consideration of all alternatives.

5. Our investment results are in the top quartile of investment managers.

This criterion often is used in the selection of managers, but it has several weaknesses. Few managers have been able to remain in that position consistently over time. Moreover, a satisfactory relative return may, on an absolute basis, be inadequate for the proper funding of the plan. As we have discussed earlier, returns relative to some market average may be useful in a multimanager environment in order to provide the justification for payment of management fees. Returns relative to some manager universe must be interpreted carefully, however, because managers in any universe may have portfolios with different investment objectives or risk tolerances. In addition, returns should be considered in the light of the risks assumed to achieve them. 


\section{All the actuarial report does is tell me the annual contribution.}

The most obvious use of the actuarial report is to learn from it the contribution range available to the company, i.e., the minimum contribution the company must make to be in compliance with the requirements of ERISA and the maximum contribution the company can make and still have the pension cost deductible for income tax purposes under the Internal Revenue Code. However, other valuable uses of the actuarial report should not be overlooked. A review of the report will indicate the funded status of the plan and also the funding process, and a discussion with the actuary should assist in determining whether the funding process currently used is the best one for the company. One of the most useful parts of the report is the summary of actuarial gains and losses, which indicates whether actuarial losses can be attributable to plan changes, or to the differences between actual experiences and the actuarial assumptions. It might also be well to review the actuarial report with the investment managers, so that they have some understanding of the funded status of the plan and the assumptions being used by the actuary. This type of discussion with the investment manager could include a review of the investment objectives to be sure they are still appropriate. 


\section{APPENDIX \\ CHECKLIST FOR THE PLAN SPONSOR}

The following checklist may assist corporate plan sponsors in reviewing the material discussed in this monograph to see how it might be adapted for their own plans. The arrangement suggests a sequence of decisions to cover most of the factors discussed in this monograph.

I. Some considerations to determine what the company can afford:

A. Labor costs (compensation plus fringe benefits) as a percent of total costs

B. Fringe benefits as a percent of total compensation costs

1. Contributions to employee benefits plans as a percent of total payroll costs

2. Contributions as a percent of pretax income

C. Compensation costs compared with those of competitors that have comparable benefit level

D. Fixed costs as a percent of total costs

E. The amount of sales decline that would threaten fixedcost coverage and the likelihood of such a decline

II. Plan characteristics:

A. Types of plans

1. Defined contribution plans
a. Profit sharing
b. Stock bonus
c. Employee stock purchase 

d. Money purchase
e. Savings and thrift
f. IRA contribution
g. Qualified voluntary employee contribution
h. $401(\mathrm{k})$

2. Defined benefit plan
a. Insured
b. Noninsured
- Fixed benefit
- Pay and service-related benefit
B. Employee coverage
C. Vesting provisions
D. Benefit payments

1. Lump sum

2. Annuity

3. Installments

E. Retirement age

F. Integration with Social Security

G. Death and disability benefits

III. Investment policies:

A. Investment return objectives

1. Time horizon to measure results 
2. Examples of absolute return objectives

Stabilize contributions as a percent of
payroll

b. Cover vested liabilities with assets at the end of some specified time period

c. Exceed the inflation rate by some target percentage

3. Examples of relative return objectives

a. Exceed the risk-free rate by a specified amount

b. Exceed some market index, e.g., the S\&P 500 Stock Index or the Lehman-Kuhn Loeb Long-Term Bond Index, by a specified amount

c. Have particular security sectors of the fund exceed comparable security market averages

d. Have the fund total return exceed that of some combination of market indexes weighted according to a predetermined asset distribution of the fund

e. Have the total fund in the upper portion of a universe of funds of comparable size, investment objectives and risk tolerances

f. In a multimanager situation, have the results of each manager compare favorably with those of other managers with comparable investment styles and managing comparable portfolios

B. Investment risk objectives

1. A stated desirable probability of meeting or exceeding a minimum return 
2. A stated desirable probability of stabilizing contributions as a percent of payroll

3. Acceptable volatility of the portfolio (standard deviation of total returns, or beta for an equity portfolio)

4. Tolerable percentage decline in asset value for a particular period

IV. Asset allocation

A. Selection of asset types

1. Stocks

2. Bonds (actively managed, immunized or contingently immunized)

3. Cash equivalents

4. Real estate debt

5. Real estate equity

6. Oil and gas and other natural resource investments

7. International security investment

8. Guaranteed income contracts

9. Option and future contracts

10. Venture capital

11. Tangible assets (gold, art, stamps, coins, etc.)

B. Type of management

1. Active management of all portions of portfolio

2. Passive management of some portions of portfolio 
3. Passive management of all of portfolio

C. Determine for each asset type selected

1. Expected returns over extended time horizon

2. Standard deviations of returns

3. Covariance of return of each asset with every other asset

D. Determine, by formal model or judgment, percent distribution of assets that will reach objectives established

1. Set liquidity needs outside of asset allocation

2. Determine variance from this allocation model that will be permitted the manager

E. Review whether liability partitioning would be desirable

1. Consider percent of plan participants who are retired

V. Manager selection:

A. Single or multimanager

1. Fee differences

2. Expected incremental return for more than one manager

3. Limits on amount of funds to be given to one manager

4. Supervision problems with more than one manager 
B. Internal vs. external management

1. Internal management capabilities

a. Personnel available and skills

b. Types of assets that could be managed

2. Internal management costs vs. outside fees

C. Determine types of assets to be externally managed

D. Select types of management styles to be used

E. Criteria for selection

1. Organization and investment decision structure

2. Number, qualifications, compensation, and experience of personnel in management organization

3. Investment philosophy and style

4. Investment results, including diversity of results among accounts

5. Importance of corporation's account to management firm

F. Degree of discretion to be given to managers

VI. Performance evaluation:

A. Time horizon for measurement

B. Market or other indexes to be used for measurement, including manager peer group measures

C. Internal vs. time-weighted rate of return to measure impact of corporate cash flow 
D. Time-weighted rates of return

1. Adjusted for risk

2. Vs. risk-free rate to determine reward for investing in risky assets

3. Vs. return if asset ratio were unchanged for period

4. Security segments of portfolio against comparable indexes

E. With more than one manager, time-weighted rates of return to determine effects of

1. Selecting different management styles

2. Distributing contributions other than equally among managers

3. Also measure managers' performance against either appropriate market indexes or manager peer group results 


\section{GLOSSARY}

This glossary has been completed by drawing as far as possible on official definitions promulgated by the actuarial and accounting professions.

\section{Accrued Benefit or Accumulated Plan Benefit}

The amount of an individual's benefit (whether or not vested) as of a specified date, determined in accordance with the terms of a pension plan and based on compensation (if applicable) and service to that date.

\section{Actuarial Accrued Liability, Actuarial Liability, Accrued Liability, or Actuarial Reserve}

That portion, as determined by a particular Actuarial Cost Method, of the Actuarial Present Value of pension plan benefits and expenses which is not provided for by future Normal Costs.

\section{Actuarial Assumptions}

Assumptions as to the occurrence of future events affecting pension costs, such as: mortality, withdrawal, disablement and retirement; changes in compensation and national pension benefits; rates of investment earnings and asset appreciation or depreciation; procedures used to determine the Actuarial Value of Assets; characteristics of future entrants for Open Group Actuarial Cost Methods; and other relevant items.

\section{Actuarial Cost Method or Funding Method}

A procedure for determining the Actuarial Present Value of pension plan benefits and expenses and for developing an actuarial equivalent allocation of such value to time periods, usually in the form of a Normal Cost and an Actuarial Accrued Liability.

\section{Actuarial Gain (Loss) or Experience Gain (Loss)}

A measure of the difference between actual experience and that expected, based upon a set of Actuarial Assumptions, during the 
period between two Actuarial Valuation dates, as determined in accordance with a particular Actuarial Cost Method.

\section{Actuarial Present Value}

The value of an amount or series of amounts payable or receivable at various times, determined as of a given date by the application of a particular set of Actuarial Assumptions.

\section{Actuarial Value of Assets or Valuation Assets}

The value of cash, investments and other property belonging to a pension plan, as used by the actuary for the purpose of an Actuarial Valuation.

\section{Aggregate Actuarial Cost Method or Aggregate Cost Method}

A method under which the excess of the Actuarial Present Value of Projected Benefits of the group included in an Actuarial Valuation over the Actuarial Value of Assets is allocated on a level basis over the earnings or service of the group between the valuation date and assumed exit. This allocation is performed for the group as a whole, not as a sum of individual allocations. That portion of the Actuarial Present Value allocated to a valuation year is called the Normal Cost. The Actuarial Accrued Liability is equal to the Actuarial Value of Assets.

\section{Defined Benefit Pension Plan}

A pension plan that specifies a determinable pension benefit, usually based on factors such as age, years of service, and salary. A plan that is subject to ERISA and considered to be a defined benefit pension plan under the Act is a defined benefit pension plan for purposes of this document.

\section{Defined Contribution Pension Plan}

A pension plan in which the employer's contributions are determined for and allocated with respect to specific individuals, usually as a percentage of compensation. The benefits are those that can be provided at retirement based on the value of the contributions allocated to the individual. 


\section{Entry Age Actuarial Cost Method or Entry Age Normal Ac- tuarial Cost Method}

A method under which the Actuarial Present Value of the Projected Benefits of each individual included in an Actuarial Valuation is allocated on a level basis over the earnings or service of the individual between entry age and assumed exit age(s). The portion of this Actuarial Present Value allocated to a valuation year is called the Normal Cost. The portion of this Actuarial Present Value not provided for at a valuation date by the Actuarial Present Value of future Normal Costs is called the Actuarial Accrued Liability.

\section{Frozen Actuarial Accrued Liability, Frozen Actuarial Lia- bility or Frozen Initial Liability}

That portion of the Actuarial Present Value of Projected Benefits which is separated as of a valuation date and frozen under certain Actuarial Cost Methods. Generally, this separated portion is the sum of an initial Unfunded Actuarial Accrued Liability and any increments or decrements in the Actuarial Accrued Liability established subsequently as a result of changes in pension plan benefits or Actuarial Assumptions.

\section{Frozen Entry Age Actuarial Cost Method or Frozen Initial Liability Method}

A method under which the excess of the Actuarial Present Value of Projected Benefits of the group included in an Actuarial Valuation, over the sum of the Actuarial Value of Assets plus the Unfunded Frozen Actuarial Accrued Liability, is allocated on a level basis over the earnings or service of the group between the valuation date and assumed exit. This allocation is performed for the group as a whole, not as a sum of individual allocations. The Frozen Actuarial Accrued Liability is determined using the Entry Age Actuarial Cost Method. The portion of this Actuarial Present Value allocated to a valuation year is called the Normal Cost.

\section{Measurement Valuation Allowance}

The valuation allowance that results from prospective recognition of experience gains and losses, changes in actuarial assumptions, 
and the net appreciation or depreciation in the fair value of plan investment assets (including both realized and unrealized gains and losses) after giving effect to the assumed rate of return for the period. The measurement valuation allowance is a component of the net pension liability.

\section{Net Pension Liability}

The pension benefit obligation, less the net assets available for benefits, plus or minus the measurement valuation allowance.

\section{Normal Cost or Normal Actuarial Cost}

That portion of the Actuarial Present Value of pension plan benefits and expenses which is allocated to a valuation year by the Actuarial Cost Method.

\section{One-Year Term Cost}

The Actuarial Present Value, as of a valuation date, of all benefits expected to become payable in the future as a result of an event or events expected to occur during a valuation year.

\section{Pension Benefit Obligation}

The Actuarial Present Value of the accumulated benefits attributed to employee service to the date of the financial statements, based on the terms of the plan. The pension benefit obligation is a component of the net pension liability.

\section{Present Value of Future Benefits (PVFB)}

The Actuarial Present Value of Projected Benefits.

\section{Projected Benefits}

Those pension plan benefit amounts which are expected to be paid at various future times under a particular set of Actuarial Assumptions, taking into account such items as the effect of advancement in age and past and anticipated future compensation and service credits. That portion of an individual's Projected Benefit allocated to service to date, determined in accordance with the terms of a pension plan and based on future compensa- 
tion as projected to retirement, is called the Credited Projected Benefit.

\section{Term Cost Method}

An Actuarial Cost Method which values ancillary benefits using One-Year Term Costs.

Unfunded Actuarial Accrued Liability, Unfunded Actuarial Liability, Unfunded Accrued Liability, or Unfunded Actuarial Reserve

The excess of the Actuarial Accrued Liability over the Actuarial Value of Assets.

Unfunded Frozen Actuarial Accrued Liability, Unfunded Frozen Actuarial Liability, or Unfunded Frozen Initial Liability

The portion of the Frozen Actuarial Liability remaining after the addition of interest and the deduction of Amortization Payments.

\section{Unit Credit Actuarial Cost Method}

A method under which the benefits (projected or unprojected) of each individual included in an Actuarial Valuation are allocated by a consistent formula to valuation years. The Actuarial Present Value of benefits allocated to a valuation year is called the Normal Cost. The Actuarial Present Value of benefits allocated to all periods prior to a valuation year is called the Actuarial Accrued Liability. 


\section{BIBLIOGRAPHY}

Bagehot, Walter. "Risk in Corporate Pension Funds." Financial Analysts Fournal, Vol. 28, No. 1 (January/February 1972) :80-84.

Black, Fischer. "Tax Consequences of Long-Run Pension Policy." Financial Analysts Fournal, Vol. 36, No. 4 (July/August 1980) :21-28.

and Moray P. Dewhurst. "A New Investment Strategy for Pension Funds." Zournal of Portfolio Management, Vol. 7, No. 4 (Summer 1981):26-34.

Block, Frank E. "Pension Accounting." A paper presented to the Institute for Quantitative Research in Finance, Captiva, Florida, May 18, 1981.

Brinson, Gary P. "Intelligently Setting a Portfolio Asset Mix." Pension World, Vol. 18, No. 3 (March 1982) :65-70.

Bulow, Jeremy I. The Effect of Inflation on the Private Pension System. NBER Conference Paper No. 103. Cambridge, Mass.: National Bureau of Economic Research, March 1981.

Condon, Kathleen, William L. Fouse and Mark P. Kritzman. Asset Allocation Decisions in Portfolio Management. Charlottesville, Virginia: Institute of Chartered Financial Analysts, 1982.

Cottle, Sidney, Leo C. Bailey, William R. Cottle, J. Michael Murphy and Roger F. Murray. Pension Asset Management: The Corporate Decisions. New York: Financial Executives Research Foundation, 1980.

Evaluation of Investment Performance. Proceedings of a Seminar on Portfolio Management Policies, Performance Measurement and Evaluation. Charlottesville, Virginia: Financial Analysts Research Foundation, 1977.

Ezra, D. Don. "How Actuaries Determine the Unfunded Pension Liability.” Financial Analysts Fournal, Vol. 36, No. 4 (July/August 1980) :43-51. 
Feldstein, Martin. Private Pensions and Inflation. NBER Working Paper No. 568. Cambridge, Mass.: National Bureau of Economic Research, October 1980.

Private Pensions as Corporate Debt. NBER Working Paper No. 703. Cambridge, Mass.: National Bureau of Economic Research, June 1981.

Gewirtz, Paul A. and Robert C. Phillips. "Unfunded Pension Liabilities... The New Myth.” Financial Executive (August 1978).

Gropper, Diane Hal. “To Immunize or Not To?" Institutional Investor, Vol. XVI, No. 2 (February 1982) :89-94.

"Pensions: The Perils of Raising Assumed Rates of Return.” Institutional Investor, Vol. XVI, No. 3 (March 1982) :77-95.

Haight, Peter V. "Investment Management-Internal or External." Pension World, Vol. 16, No. 11 (November 1980) $: 20-24$.

Krass, Stephen J. and Richard L. Keschner. The Pension Answer Book. Greenvale, N.Y.: Panel Publishers, 1981.

McGinn, Daniel F. Pension Funding: Actuarial Primer for Corporate Management. Chicago: Charles D. Spencer \& Associates, Inc., 1980.

Mennis, Edmund A., Jerome L. Valentine and Daniel L. Mennis. "New Perspectives on Pension Fund Management." Fournal of Portfolio Management, Vol. 7, No. 3 (Spring 1981):46-50.

Munnell, Alicia H. The Economics of Private Pensions. Washington, D.C.: Brookings Institution, 1982.

Norby, William C. “Accounting for Pension Liabilities." Financial Analysts Fournal, Vol. 37, No. 4 (July/August 1981):22-23, 73-79.

Rudd, Andrew. "Social Responsibility and Portfolio Performance." California Management Review, Vol. 23, No. 4 (Summer 1981):55-61. 
Stolte, Myron D. "Pension Plan Sponsors: Monitor Yourselves." Harvard Business Review, Vol. 59, No. 2 (March/April 1981) :136-143.

Tepper, Irwin. "Taxation and Corporate Pension Policy." Journal of Finance, Vol. 36, No. 1:1-13.

"The Future of Private Pension Funding." Financial Analysts Fournal, Vol. 38, No. 1 (January/February 1982) :25-31.

Treynor, Jack L., Patrick J. Regan and William W. Priest, Jr. The Financial Reality of Pension Funding Under ERISA. Homewood, Il.: Dow Jones-Irwin, 1976.

Williams, Arthur, III. Managing Your Investment Manager. Homewood, Il.: Dow Jones-Irwin, 1980.

Wittebort, Suzanne. “Accounting for Pension Liabilities." Institutional Investor, Vol. XV, No. 12 (December 1981) :89-104. 